Article

\title{
Prediction of Muddy Floods Using High-Resolution Radar Precipitation Forecasts and Physically-Based Erosion Modeling in Agricultural Landscapes
}

\author{
Phoebe Hänsel ${ }^{1, *}$, Stefan Langel ${ }^{2}$, Marcus Schindewolf ${ }^{3}$, Andreas Kaiser ${ }^{4}$, Arno Buchholz ${ }^{1}$, \\ Falk Böttcher ${ }^{5}$ and Jürgen Schmidt ${ }^{1}$ \\ 1 Soil and Water Conservation Unit, Technical University Bergakademie Freiberg, Agricolastraße 22, \\ 09599 Freiberg, Germany; Arno.Buchholz@tbt.tu-freiberg.de (A.B.); jschmidt@tu-freiberg.de (J.S.) \\ 2 IPROconsult $\mathrm{GmbH}$, Schnorrstrasse 70, formerly Technical University Bergakademie Freiberg, \\ 01069 Dresden, Germany; Stefan.Langel@iproconsult.com \\ 3 Thüringer Landesamt für Landwirtschaft und Ländlichen Raum, Referat 21 Futtermittel- und \\ Marktüberwachung, Düngung und Bodenschutz, Naumburger Strate 98, 07743 Jena, Germany; \\ marcus.schindewolf@tlllr.thueringen.de \\ 4 Institute of Geography, Friedrich Schiller University Jena, Löbdergraben 32, 07743 Jena, Germany; \\ kaiser.andreas@uni-jena.de \\ 5 Deutscher Wetterdienst, Abteilung Agrarmeteorologie, Kärrnerstraße 68, 04288 Leipzig, Germany; \\ Falk.Boettcher@dwd.de \\ * Correspondence: Phoebe.Haensel@tbt.tu-freiberg.de; Tel.: +49-371-39-2679
}

Received: 31 July 2019; Accepted: 7 September 2019; Published: 16 September 2019

\begin{abstract}
The monitoring, modeling, and prediction of storm events and accompanying heavy rain is crucial for intensively used agricultural landscapes and its settlements and transport infrastructure. In Saxony, Germany, repeated and numerous storm events triggered muddy floods from arable fields in May 2016. They caused severe devastation to settlements and transport infrastructure. This interdisciplinary approach investigates three muddy floods, which developed on silty soils of loess origin tending to soil surface sealing. To achieve this, the study focuses on the test of a historical forecast modeling of three muddy floods in ungauged agricultural landscapes. Therefore, this approach firstly illustrates the reconstruction of the muddy floods, which was performed by high-resolution radar precipitation data, physically-based erosion modeling, and the qualitative validation by unmanned aerial vehicle-based orthophotos. Subsequently, historical radar precipitation forecasts served as input data for the physically-based erosion model to test the forecast modeling retrospectively. The model results indicate a possible warning for two of the three muddy floods. This method of a historical forecast modeling of muddy floods seems particularly promising. Naturally, the data series of three muddy floods should be extended to more reliable data and statistical statements. Finally, this approach assesses the feasibility of a real-time muddy flood early warning system in ungauged agricultural landscapes by high-resolution radar precipitation forecasts and physically-based erosion modeling.
\end{abstract}

Keywords: storm event; heavy rain; muddy flood; soil erosion; radar precipitation data and forecasts; physically-based erosion modeling; UAV monitoring; early warning system; agricultural landscapes; loess

\section{Introduction}

The monitoring, modeling, and prediction of storm events and accompanying heavy rain is not only crucial for urban areas, but for agricultural landscapes and its settlements and transport 
infrastructure as well. Storm events occurring over sparsely vegetated or exposed arable fields can trigger muddy floods. Beside the on-site impacts of soil loss and decreasing soil fertility on the field, these large amounts of muddy runoff inundate neighboring traffic routes, settlements, and water ecosystems.

The term muddy flood has been used since the late 1980s in western and central Europe [1,2]. It does not refer to the hyperconcentrated flows produced from mountains and/or badlands in the Mediterranean and alpine environments [1]. Muddy floods often occur in areas with silty or loamy soils tending to crust [2] due to soil surface sealing [3,4]. Especially the fertile, but fragile soil landscapes dominated by loess tend to soil surface sealing due to their low aggregate stability [3,5]. With raindrop impact the soil aggregates break down, are transported with the flowing water, seep into the soil, and form densely packed sedimentation layers [4]. Due to associated reduced infiltration, these soils are sensitive in case of heavy rain [5], especially if they are located on slopes [4].

In late spring 2016, a persistent macro-atmospheric weather condition with repeated and numerous storm events dominated weather conditions in Germany [6]. They triggered muddy floods, flash floods, and landslides, causing severe devastations of transport infrastructure and settlements throughout Germany and also casualties in Bavaria [6,7]. In Saxony, the long-distance railway line 'Dresden-Prague' between Germany and the Czech Republic was closed twice due to two muddy floods within eight days at the end of May. In the evening hours on 23 May 2016, a muddy flood happened due to a storm event near Reinhardtsdorf-Schöna. Stones and small tree trunks were carried away by the muddy runoff passing the downslope forest, which was affected by clear cutting at that time. Finally, the dirt deposited on the railway tracks and caused a freight train to derail. Fortunately, nobody was injured, but material damage was reported [8]. In the afternoon on 31 May 2016, another muddy flood happened due to another storm event at the same place. The line had to be closed again [9]. Another muddy flood was reported in the small town of Oberbobritzsch in middle Saxony after a storm event in the afternoon on 27 May 2016. The muddy runoff entered a district road and flew down the small town. As a result, the roads were covered by mud and had to be cleared again [10].

With radar precipitation data, the area-wide spatial distribution of precipitation becomes possible for the first time. These data in high spatio-temporal resolution also help to detect individual storm cells. Moreover, it is possible to identify their size, location, and intensity [11].

Heavy rain and soil erosion have been modeled by radar precipitation data. Fischer et al. [12] have published a dataset as a result of their preliminary work [13-15], which comprises the mean annual precipitation erosivity, or the $\mathrm{R}$ factor. This dataset is based on a new calibrated radar precipitation dataset from the German Meteorological Service (DWD) for the climatological analysis of precipitation extremes in Germany [16]. The R factor enables determining the soil erosion risk of agricultural fields [12]. As part of the empirical erosion model the Universal Soil Loss Equation (USLE), it is dependent on the dataset from which it has been derived [17].

Deumlich [18] utilized radar precipitation data as input data for the physically-based erosion model EROSION 3D (E 3D) to analyze on-site impacts due to soil erosion on agricultural fields after heavy rain in Brandenburg, Germany, in 2007. Indeed, in comparison to the actual soil loss, the modeled soil loss was underestimated. According to the author, this modeled underestimation is presumably a result of ridge and furrow fields. Hänsel et al. [19] reconstructed the two aforementioned muddy floods near Reinhardtsdorf-Schöna with E 3D, high-resolution radar precipitation data, and unmanned aerial vehicle (UAV) monitoring. Thereby, inter alia, it was indicated that the currently best 5-min (min) radar precipitation product, which is solely generated by radar data, underestimated these two heavy rain events. Thus, the muddy floods would not have been developed with these precipitation data within the modeling.

The overall objective of this interdisciplinary study was to test the method of a historical forecast modeling of the aforementioned muddy floods in ungauged catchments of agricultural landscapes. This testing of a forecast modeling was carried out by means of area-wide, high-resolution radar precipitation forecasts of the DWD and high-resolution physically-based erosion modeling with E 3D. 
In a first step, a new and calibrated radar precipitation dataset in 5-min time steps [20] was analyzed and compared to two other uncalibrated 5-min radar precipitation products with regard to the suitability of precipitation for the two study areas. Furthermore, these new radar precipitation data were used to visualize the precipitation situation of the three storm events triggering the muddy floods in the form of radar images. In a further step, these new data were utilized as meteorological input data for E 3D to reconstruct the three muddy floods. This reconstruction was qualitatively validated by UAV-based orthophotos. In a last step, historical real-time radar precipitation forecasts of 2016 served as input data for E 3D to test the forecast of the muddy floods retrospectively. Additionally, the resulting erosion risk and surface runoff maps locate sediment and runoff entry points. Finally, this approach assesses the feasibility of a real-time muddy flood early warning system in ungauged agricultural landscapes by high-resolution radar precipitation forecasts and physically-based erosion modeling.

\section{Materials and Methods}

\subsection{Study Areas}

The study areas are situated within the Federal State of Saxony, Germany. Reinhardtsdorf-Schöna is located in the immediate vicinity of the Czech border, Oberbobritzsch almost $55 \mathrm{~km}$ west of it (Figure 1a). Each of the areas covers almost $1 \mathrm{~km}^{2}$.

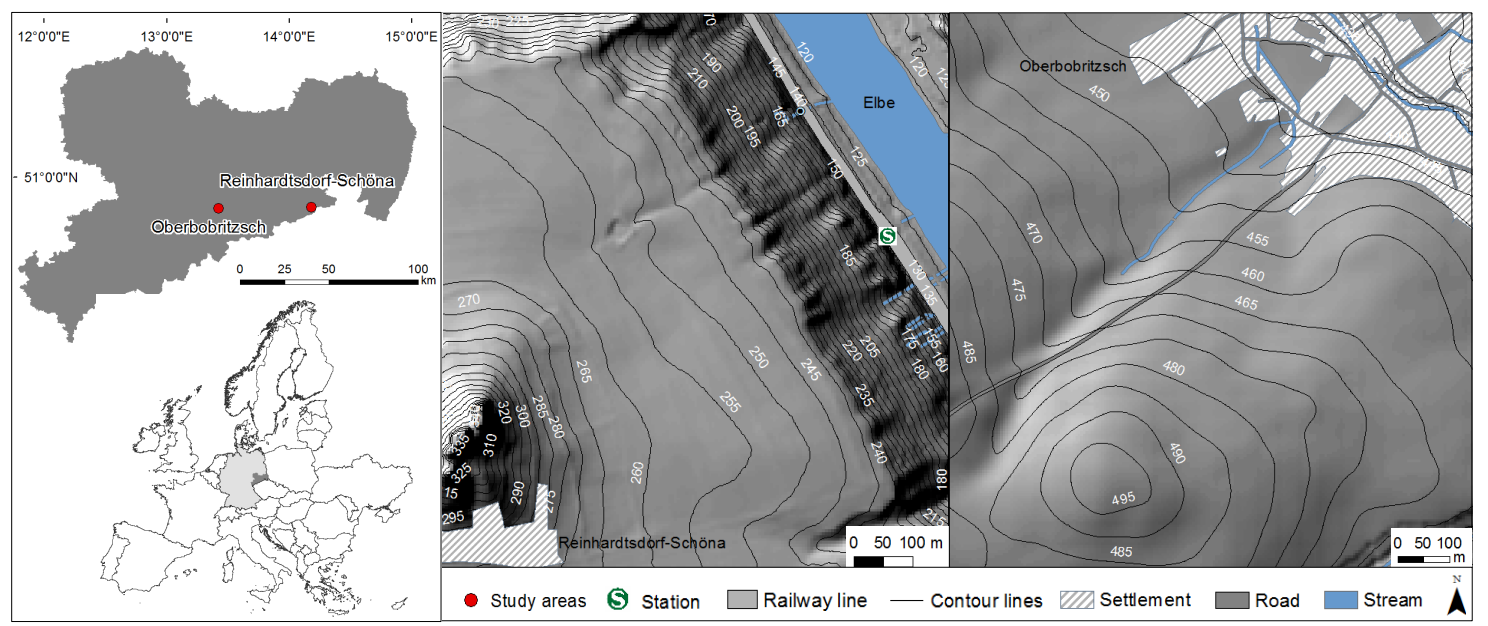

Figure 1. The study areas in (a) Saxony, Germany, and Europe (data basis: [21]), (b) the relief of Reinhardtsdorf-Schöna and (c) of Oberbobritzsch.

Reinhardtsdorf-Schöna is located in the Elbe Sandstone Mountains and is crossed by the river Elbe in the northeastern part (Figure 1b). The long-distance Dresden-Prague railway line runs parallel to the river Elbe. Adjacent to it is the steep and wooded slope of the Elbe Valley. The highest point of the study area features the rocks of the mountain 'Kaiserkrone' $335 \mathrm{~m}$ above sea level, whereas the central part is gently sloped. These gently sloped areas are used as cropland. At the DWD station Lichtenhain-Mittelndorf, which is situated $5 \mathrm{~km}$ to the north, the mean annual precipitation is $839 \mathrm{~mm}$, and the mean annual temperature is $8.4^{\circ} \mathrm{C}$ [22]. The study area belongs to the soil region of mountainous and hilly regions with high sandstone amounts. Therefore, the soils on the underlying hard or loose rock are relatively shallow. The soil texture of the wooded slope consists of pure sand, whereas the gently sloped agricultural lands are comprised of weak clayey silt [23]. The latter tends to strong soil surface sealing [5]. The corresponding soil type of the forest is classified as a Podzol, while that of the fields is a loess Luvisol [23].

The second study area is located in the lower Eastern Ore Mountains. Its northeastern part comprises a part of the small town Oberbobritzsch, which is crossed by the stream Bobritzsch (Figure 1c). The terrain slightly rises to southwest. It is dominated by agriculture and divided by a district road. At Oberbobritzsch, the mean annual precipitation is $850 \mathrm{~mm}$ [24], and the mean annual temperature 
for this region is $8.2^{\circ} \mathrm{C}$ [22]. Mostly, the texture of the shallow soils on underlying gneiss comprise sandy-loamy silts and silty-loamy sands [23]. Especially the sandy-loamy silts pertain to the soils tending to middle and strong soil surface sealing [5]. The corresponding soil type of these soil textures is classified as Cambisols of silt and/or grit [23].

\subsection{High-Resolution Radar Precipitation Data and Forecasts}

\subsubsection{Data Description}

This study utilizes the high-resolution spatio-temporal radar precipitation data of the RADOLAN procedure, the RADKLIM project, and the radar precipitation forecasts of the RADVOR of the three muddy floods.

The term RADOLAN stands for the German term RADar-OnLine-ANeichung, meaning radar online adjustment. This procedure comprises a wide range of real-time, area-wide radar precipitation products in different processing steps and temporal resolutions. These remotely and indirectly measured radar products range from 5-min time steps over $1 \mathrm{~h}$ to 30 days, and have a spatial resolution of $1 \mathrm{~km}^{2}$ [25]. Thereof, the hourly radar precipitation product is called RW, and is adjusted by rain gauge data operationally every $10 \mathrm{~min}$ [26]. The 5-min products RZ and RY are used by this study (see Table 1). Though they are unadjusted by rain gauge data, the RZ-product provides more plausible data in cases of high amounts of precipitation $[11,19]$. In contrast, the RY-product is quality tested by further radar errors [25] and of higher quality in cases of little to moderate precipitation [11,19]. Furthermore, RY has the best quality, which is currently possible due to it being solely generated by radar data [11]. Both real-time radar precipitation products help assess the new 5-min YW-dataset of the RADKLIM project [20] (see Table 1) with regard to the suitability of precipitation for the reconstruction modeling of the three muddy floods. RADKLIM is the abbreviation of the German term RADarKLIMatologie, meaning radar climatology. These high-resolution radar-based precipitation rates form the basis for the climatological analysis of precipitation extremes in Germany. They comprise RADOLAN data, which is completely new and processed with the latest version of the RADOLAN procedure covering the time period from 2001 until 2017. Thus, the 5-min YW-products are reprocessed radar precipitation data being quasi-calibrated with the hourly, gauge-adjusted RW-product [27] (see Table 1).

Table 1. The 5-min radar precipitation products used by this study, as well as their procedure and characteristics.

\begin{tabular}{ccc}
\hline Product & Procedure & Characteristics \\
\hline RZ & RADOLAN & real-time, unadjusted to rain gauges \\
RY & RADOLAN & real-time, quality tested, unadjusted to rain gauges \\
YW & RADKLIM & reprocessed, quasi-gauge adjusted \\
RV & RADVOR & real-time, forecasted, basis: RY, unadjusted to rain gauges \\
\hline
\end{tabular}

Furthermore, this study involves historical real-time radar precipitation forecasts of the RADVOR procedure for testing the historical forecast of the muddy floods. The term RADVOR is abbreviated from the German RADar-NiederschlagsVORhersage, meaning radar precipitation forecast. These high spatio-temporal radar precipitation forecasts have lead times up to $2 \mathrm{~h}$. The idea of nowcasting-short-term forecasting-is to identify and track similar precipitation structures in radar-based precipitation images. Subsequently, this displacement is determined and extrapolated in 5-min time steps up to $2 \mathrm{~h}$ into the future. The RADVOR procedure comprises several products. One of them is the RV-product, having a temporal resolution of $5 \mathrm{~min}$ and a spatial resolution of $1 \mathrm{~km}^{2}$ [28] (see Table 1). The basis for the RV-product is the quality tested RY-product of the RADOLAN procedure [29]. The RV data of May 2016 were generated primarily by the extrapolation of stratiform precipitation fields. Additionally, short-lived, convective structures were also identified [30]. As these 
high-resolution and area-wide precipitation forecasts are updated every $5 \mathrm{~min}$, the data of rain gauges for adjustment purposes are presently not available [28].

\subsubsection{Data Preparation and Analysis}

The real-time radar precipitation products RZ and RY and the real-time radar precipitation forecasting product RV were provided for this study by the DWD. Meanwhile, the RY data are freely available via the open data server of the DWD at the time of the data query for the last two days [31]. The YW-product is freely available, too [20]. These products contain binary coded grid data [32], which require the appropriate software application for external users. One of these applications is Wradlib, which is an open source library for weather radar data processing. Wradlib is written in the free programming language Python, and assists with reading, converting, and visualizing weather radar data [33]. Additionally to the binary format, the YW-product is also provided in the Geographic Information Systems (GIS)-compatible ASCII format via the open data server of the DWD [20].

For the reconstruction and the historical forecast modeling, it was necessary to read out and analyze these radar precipitation products. Therefore, a Python script on the basis of Wradlib was written to read and automatically write the precipitation intensities of the RZ-, RY-, and RV- products, as well as a defined area in a CSV file. This file with its calculated precipitation intensities for every minute provides not only the actual precipitation intensities for analytical purposes (see Section 3.1), but also serves as meteorological input data for E 3D. Analytical purposes include the assessment of the intensity of the three storm events in 5-min, 10-min, and one-hour increments (Table 2). Correspondingly, heavy rain is characterized by a precipitation amount greater than or equal to $0.8 \mathrm{~mm}$ in five minutes and $10 \mathrm{~mm}$ in one hour, respectively [34].

Table 2. The classification of the intensity of precipitation per time unit [34].

\begin{tabular}{|c|c|c|c|}
\hline Intensity & $\mathrm{mm} / 5 \mathrm{~min}^{1}$ & $\mathrm{~mm} / 10 \mathrm{~min}$ & $\mathrm{~mm} / \mathrm{hr}$ \\
\hline Light & $<0.2$ & $<0.5$ & $<2.5$ \\
\hline Moderate & $\geq 0.2-<0.8$ & $\geq 0.5-<1.7$ & $\geq 2.5-<10.0$ \\
\hline Heavy & $\geq 0.8-<4.2$ & $\geq 1.7-<8.3$ & $\geq 10.0-<50.0$ \\
\hline Very heavy & $\geq 4.2$ & $\geq 8.3$ & $\geq 50.0$ \\
\hline
\end{tabular}

Thereby, the three storm events could be classified according to their intensity of precipitation. Subsequently, the storm events were visualized as radar images by means of the YW product in the GIS-compatible ASCII format in the open source GIS QGIS [35] (see Section 3.1.2). Additionally, they were assessed according to the KOSTRA-DWD-2010R. The German term KOSTRA-DWD-2010R is abbreviated from the German 'KOordinierte STarkniederschlagsRegionalisierung und Auswertung des DWD', and is known for the coordinated regionalization and analysis of heavy precipitation by the DWD. This revised raster dataset covering the time period from 1951 to 2010 helps to assess storm events on the basis of their duration of precipitation and according to their return period [36].

\subsubsection{Comparison of Radar Precipitation Data and Rain Gauge Data}

The comparison of the indirectly measured radar precipitation data and the actually measured amounts of heavy rain at the rain gauge stations was performed in order to assess the new 5-min YW dataset of the DWD. This assessment enables the selection of the most suitable area-wide radar precipitation product for the two study areas and the most probable model results of the three muddy floods.

The nearest rain gauge station to Reinhardstdorf-Schöna is Lichtenhain-Mittelndorf (Figure 6). This precipitation monitoring station of the DWD is situated $5 \mathrm{~km}$ north of the study area and provides amounts of precipitation for every minute. The small town Oberbobritzsch has a rain gauge station situated $1 \mathrm{~km}$ south of the study area, and makes daily amounts of precipitation available. The 
precipitation amounts of the rain gauge stations are freely available via the Open Data Server of the DWD $[37,38]$.

\subsection{High-Resolution Physically-Based Erosion Modeling Using EROSION 3D}

E 3D is a physically- and process-based model that simulates the detachment and transport of soil by water in catchments of agricultural landscapes. It is capable of simulating extreme precipitation events. As a computer-aided and grid-based model, it is also compatible with GIS [39]. Furthermore, E 3D has been applied and validated in numerous catchments [17,19,40-51]. Recent publications also deal with the generation of erosion risk maps for Saxony [19,49,50,52]. Depending on the resolution of the input Digital Terrain Model (DTM), these maps—and also the modeled surface runoff maps—can be of high resolution. E 3D is well documented [39] and validated [53-57].

\subsubsection{Modeling Approach}

The theoretical principles of E 3D for simulating rainfall erosion were developed by Schmidt $[17,58]$. Initially, these principles were implemented in the model EROSION 2D [17,59], which was the slope profile version. In the following years, von Werner developed the catchment area version EROSION 3D, particularly for the prediction of soil erosion in small, ungauged catchments [60]. Thereby, the sub-processes of soil erosion are executed as follows (Figure 2): infiltration of precipitation, runoff generation, detachment of soil particles from the ground, particle and associated pollutant transport, as well as deposition, depending on the transport capacity of the surface runoff and the enrichment of soil particles along the transport path [39]. According to the model's infiltration model, infiltration is modeled using the Green-Ampt approach [61], and the infiltration rate is calculated with the Darcy equation [17]. Moreover, a flow path model derived from a DTM is used for the spatial distribution of the surface runoff [62]. Thereby, the surface runoff is distributed between the actual raster cell and its adjacent, deeper-lying, direct 8 neighbors, depending on their relative height difference [39]. Finally, particle detachment and transport are simulated by the momentum flux approach by Schmidt $[17,58,59]$ via the erosion model.
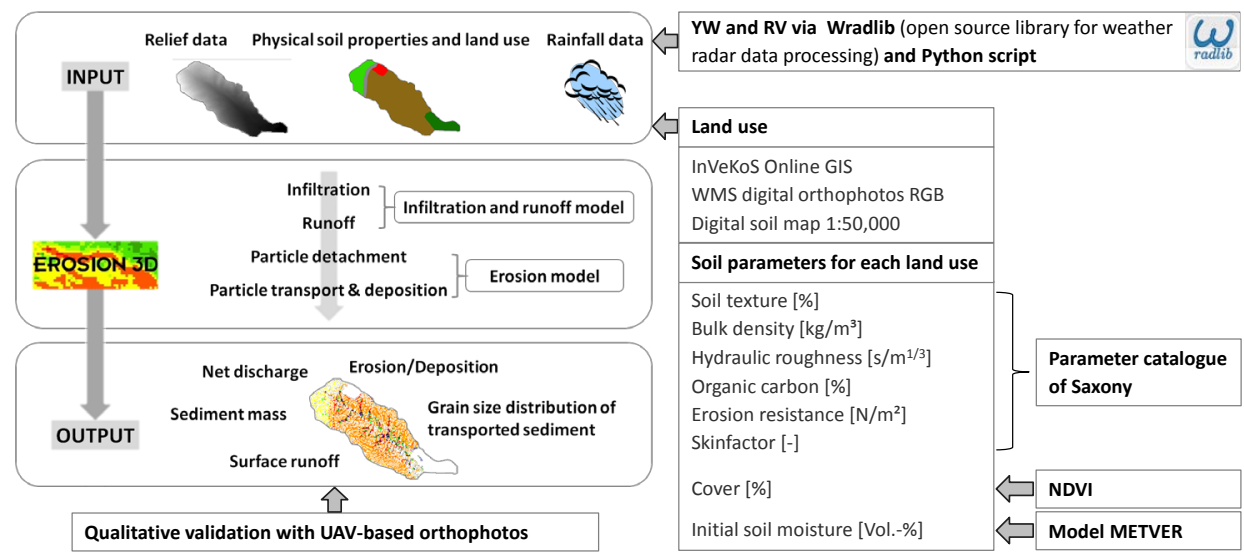

Figure 2. Program sequences (changed after [63]) and parameterization of EROSION 3D (E 3D) as well as the methods and data sources used by this study.

Figure 2 describes not only the individual program sequences of $\mathrm{E} 3 \mathrm{D}$, but also the model input and output data. E 3D requires three input datasets. A DTM is the basis for the relief dataset. A digital soil and land-use grid is the basis for the soil and land use dataset. Precipitation data with a resolution of $10 \mathrm{~min}$ or higher serve as meteorological input data [39].

Besides the digital soil and land-use grid, the soil and land-use dataset requires the physical soil properties in form of a table.

For modeling soil erosion, seven soil parameters have to be determined (see Figure 2):

1. bulk density $\left[\mathrm{kg} / \mathrm{m}^{3}\right]$ 
2. organic carbon [\% by weight]

3. initial soil moisture [\% by volume]

4. hydraulic roughness $\left[\mathrm{s} / \mathrm{m}^{1 / 3}\right]$

5. resistance to erosion $\left[\mathrm{N} / \mathrm{m}^{2}\right]$

6. cover [\%], and

7. soil texture [\% by weight] [39].

Additionally, E 3D offers the so-called skin factor, which enables to consider initially neglected influences on the infiltration rate such as macropore flow, soil compaction, or soil surface sealing. This skin factor can correct these influences on the infiltration rate [17]. During the soil erosion measurement program for Saxony, an extensive database for the parameterization of the soil parameter table was created by 116 rainfall simulations on erosion-prone slopes [53-57]. These rainfall simulations are also documented in the parameter catalogue of Saxony [64] and in the freely available database of 726 rainfall simulation experiments for surface runoff from arable land [65]. Thereby, the corresponding soil parameters can be determined depending on the land use, agricultural type of use, soil cultivation, and soil texture. Moreover, these soil data are also included in software for the automated parameterization of soil parameters, the database-processor (DPROC). By means of the DPROC, it is possible to automatically assign the soil parameters of a given Digital Landscape Model (DLM) $[66,67]$.

In the case of short-term heavy rain events, E 3D initially models the infiltration, assuming that runoff generation and erosion are predominantly dependent on the soil properties of the top soil layer. This assumption of the one-layer model is not valid in the case of persistent precipitation and shallow soils on water-impermeable subsoils or bedrocks. In these cases, E 3D is able to simulate the infiltration in the underlying subsoils by means of the multiple-layer infiltration-extension [47,48].

\subsubsection{Model Parameterization}

This study utilizes two DTMs with a resolution of $5 \mathrm{~m}$ for the generation of the relief datasets of the two study areas. This resolution was chosen to guarantee sufficiently precise erosion and deposition patterns and surface runoff generation in case of a possible warning by an early warning system at a manageable computing time. The basis for the DTM of Reinhardtsdorf-Schöna is a DTM with a resolution of $2 \mathrm{~m}$ [68], which was resampled and downscaled in the open source GIS QGIS [36]. The 10-m DTM of Oberbobritzsch [69] was resampled and upscaled to a resolution of $5 \mathrm{~m}$.

The radar-based precipitation intensities of the YW-data and RV data in 5-min time steps (see Figure 2) and a precipitation duration of $2 \mathrm{~h}$ serve as meteorological input data for $\mathrm{E} 3 \mathrm{D}$. Thereby, one RADOLAN grid cell of $1 \mathrm{~km}^{2}$ for each study area was selected, covering the small ungauged catchments very well. Due to the comparison of radar precipitation data and rain gauge data (see Section 3.1.1), the YW-product was used for the reconstruction of the three muddy floods. The historical forecast was modeled by means of the RV-product.

The required soil and land-use grid of the soil and land-use dataset for both study areas was generated by the union and raster converting of the digitalized land use by means of InVeKoS Online GIS [70], the WMS digital orthophotos RGB [71], and the digital soil map 1: 50,000 [23] in ArcGIS [72] (see Figure 2). The soil parameters of the soil parameter table were determined according to the parameter catalogue [64], except for the parameters 'initial soil moisture' and 'cover' (see Figure 2). Thereby, the effect of soil surface sealing was considered for determining the skin factor of the soils. As silty soils with a high proportion on coarse silt are sensitive to heavy rain [5], which is indicated in the radar precipitation data of the previous days, it can be expected that soil surface sealing in these silty soils occurred. The soil parameters of missing anthropogenic land uses in the parameter catalogue such as settlements, roads, clear cutting, and skid trails (see Section 2.3.3) were adapted following the later research work of Arévalo [73] and the findings of Zemke [74] (see also [19]). Furthermore, the multiple-layer infiltration-extension was used in this study due to the shallow soils of the study 
areas underlain by water-impermeable rock. The parameterization of the soil parameters of the underlying soil layer was adopted following Seidel [47].

As soil moisture is subject to temporal and spatial fluctuations due to weather and soil conditions [4], the initial soil moisture was modeled with the water balance model METVER (see Figure 2). The term METVER is abbreviated from the German term METeorologisches VERdunstungsmodell, meaning meteorological evaporation model. It is used and updated by the DWD. This model was designed for use in agricultural landscapes, and is able to calculate the daily soil moisture. It is a further development of the model of Müller and Müller [75-77], and is based on the determination of real and the potential evaporation. Thereby, the potential evaporation is determined by the method of Wendling and Schellin [78], which is based on the method of Turc [79]. METVER requires meteorological input data such as daily mean temperature, daily precipitation sum, and sunshine duration, as well as the soil input data soil texture, field capacity, and permanent wilting point for modeling soil moisture [80]. For the initial soil moisture of Reinhardtsdorf-Schöna, the mean value of the soil moisture of the nearest three weather stations (Lichtenhain-Mittelndorf, Dresden-Hosterwitz and Dippoldiswalde-Reinberg) was used. The modeled soil moisture at the weather station of Dippoldiswalde-Reinberg was utilized for the initial soil moisture of Oberbobritzsch.

\subsubsection{Derivation of E 3D's Soil Parameter 'Cover' from NDVI}

The soil and land-use dataset of E 3D also contains, besides the soil data, information about the actual land use. Figure $3 a$ visualizes the land use of Reinhardtsdorf-Schöna at the time the muddy floods happened. Reinhardtsdorf-Schöna is characterized by different land uses: meadows, forests, settlements, infrastructure, and the river Elbe. The soil texture of the maize fields in the central part of the study area consists of weak clayey silt tending to strong soil surface sealing [5]. At that time, the forest was affected by clear cutting and associated skid trails.

At present, there exists an estimation panel in the parameter catalogue to assess E 3D's soil parameter 'cover' non-automatically. By means of the Normalized Difference Vegetation Index (NDVI) being a reliable method to predict agricultural production [81], the method was tested to estimate the cover of agricultural fields (see Figure 2). Figure $3 \mathrm{~b}$ illustrates the corresponding NDVI of Reinhardtsdorf-Schöna. The Land Viewer NDVI product, which is a web interface for satellite imagery of the company EOS, was used to derive the E 3D soil parameter 'cover'. By means of the NDVI, sparsely vegetated arable fields were identified. The NDVI reflects the relative biomass, as it is calculated by the red band and the near-infrared band of a satellite scene. There, the red band includes information about chlorophyll absorption, and the near-infrared band includes information about the reflectance of vegetation. The NDVI was acquired from Sentinel-2 on 29 May 2016, and indicates for the bright green maize fields a value of 0.25 [81]. Consequently, the E 3D soil parameter 'cover' can be estimated at $15 \%$.

Figure $4 \mathrm{a}$ visualizes the land use of Oberbobritzsch. Besides the settlement in the northwestern part of the study area, the land use is dominated by agricultural fields. Summer cereal, rapeseed, spring barley, peas, and maize fields are located between the grey winter cereal fields. The soil of the peas and maize field on the southeastern side of the district road comprises sandy-loamy silts. They tend to middle and strong soil surface sealing [5]. Meadows can be found near the settlement areas and along streams and ponds. 


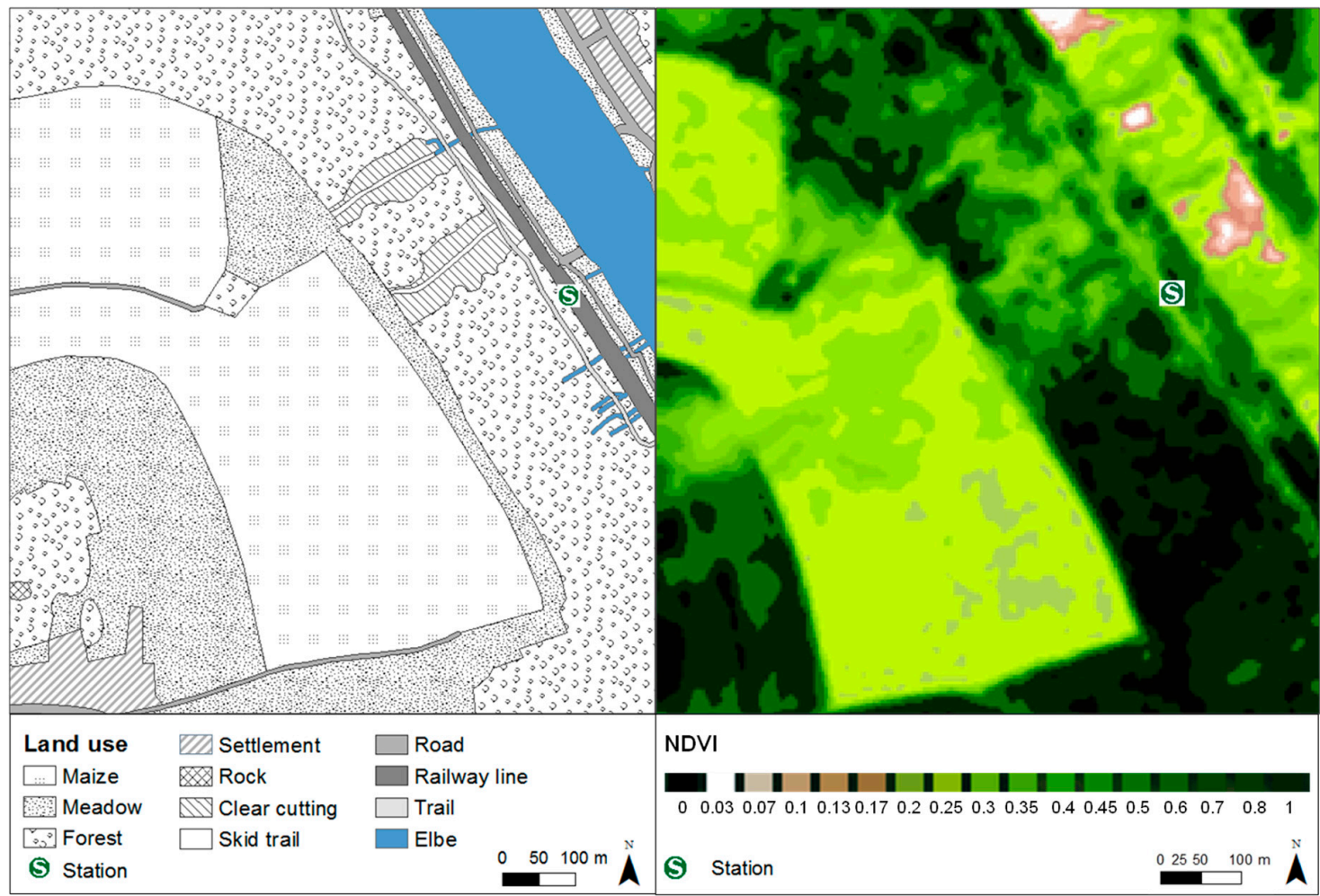

(a)

(b)

Figure 3. The (a) land use and (b) Normalized Difference Vegetation Index (NDVI) of Reinhardtsdorf-Schöna [81].

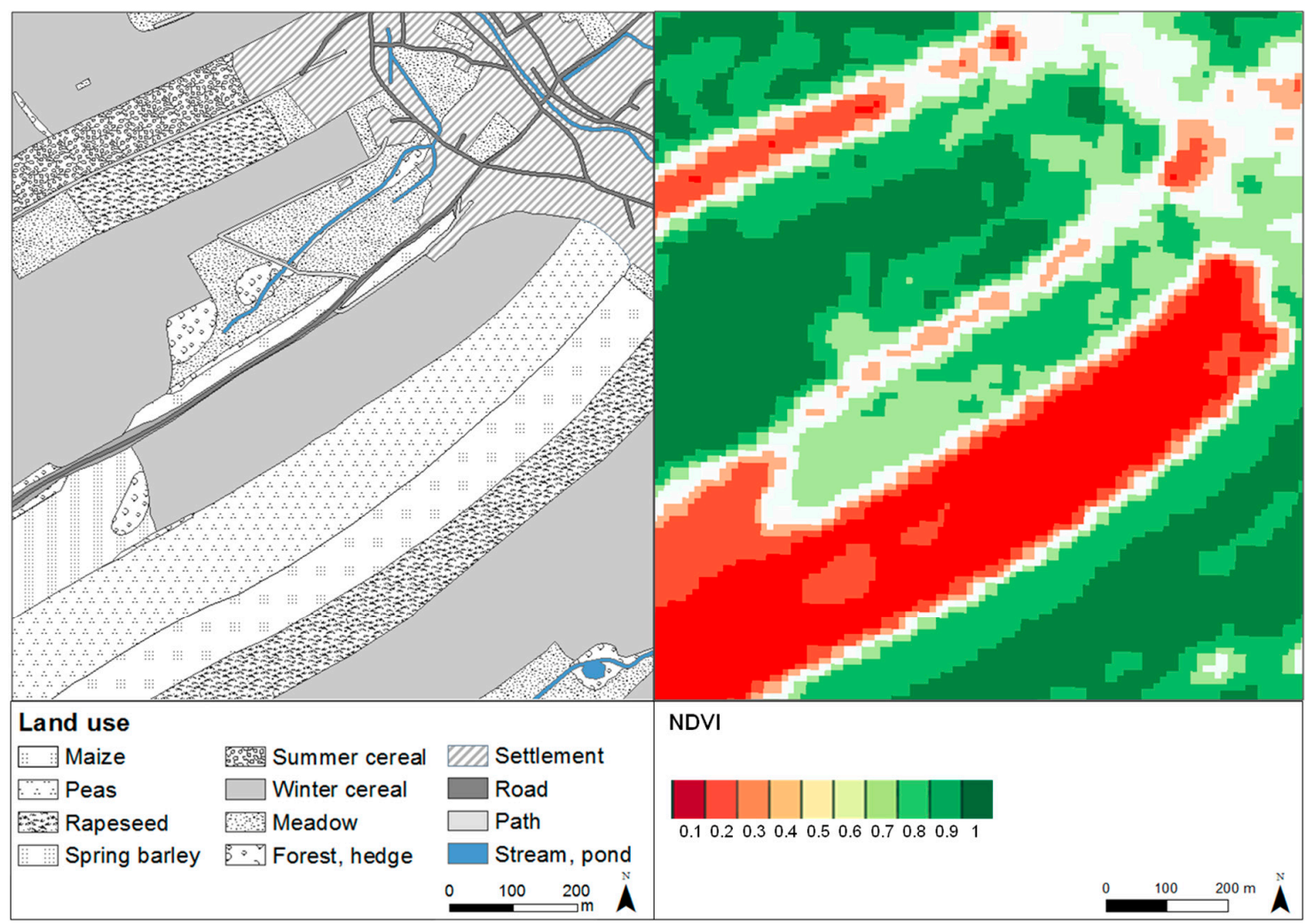

(a)

(b)

Figure 4. The (a) land use and (b) NDVI of Oberbobritzsch [81]. 
The corresponding NDVI of the study area (Figure 4b) was acquired from Landsat 8 on 7 May 2016 [81]. The dark red maize and peas field indicate a NDVI of 0.1. Accordingly, the E 3D soil parameter 'cover' was estimated at $10 \%$.

\subsection{Qualitative Model Validation by UAV Monitoring}

For this study, the results of the three reconstructed muddy floods modeled with E 3D were qualitatively validated with UAV-based orthophotos (see Figure 2). For this, the study areas were mapped with a camera-equipped UAV after the muddy floods happened. For Reinhardtsdorf-Schöna, the UAV flight was performed one day after the last muddy flood, on 1 June 2016. The study area of Oberbobritzsch was monitored by UAV on 31 May 2016, four days after the muddy flood. After the UAV flights, the generated orthophotos were compared to the high-resolution, modeled erosion patterns and sediment source areas.

The UAV used for monitoring was a 'Phantom 2' (quadrocopter) from DJI Innovations (Shenzhen, China). It was equipped with a digital 'PowerShot S100' from Canon (Tokyo, Japan). The camera had image stabilization, allowing it to maintain the stability and quality while acquiring photos. Additionally, an internal GPS receiver allows for initial referencing of the camera positions, and accordingly the surveyed area. About 700 overlapping images were taken to guarantee sufficient overlap for covering the erosion patterns, as well as the sediment source areas.

Subsequently, the overlapping images were processed with Structure from Motion (SfM) photogrammetry and multi-view dense matching methods in Agisoft PhotoScan [82], which is now Agisoft Metashape. Then, the resulting dense point cloud was used for orthophoto generation.

\section{Results}

\subsection{High-Resolution Radar Precipitation Data and Forecasts}

The 5-min radar precipitation products RZ, RY, and YW as well as the radar precipitation forecasting product RV were analyzed concerning their precipitation sum and precipitation intensity, in accordance with rain gauge data. The diagrams and figures of the following subsections describe these analyses of the three storm events on 23 May, 27 May, and 31 May 2016.

\subsubsection{Comparison of Radar Precipitation Data and Rain Gauge Data}

Figure 5 illustrates the precipitation sum $\left(\sum \mathrm{P}\right)$ for the three radar precipitation datasets RZ, RY, and YW, and rain gauge data at the corresponding rain gauge station on 23 May (Lichtenhain-Mittelndorf), 27 May (Oberbobritzsch), and 31 May 2016 (Lichtenhain-Mittelndorf). The precipitation sum for Lichtenhain-Mittelndorf is stated in mm within two hours, and for Oberbobritzsch, it is stated in mm per day. The dashed line marks the measured precipitation at the rain gauge as $100 \%$. The positive or negative deviations from this value are specified for the RZ-product, RY-product, and YW-product.
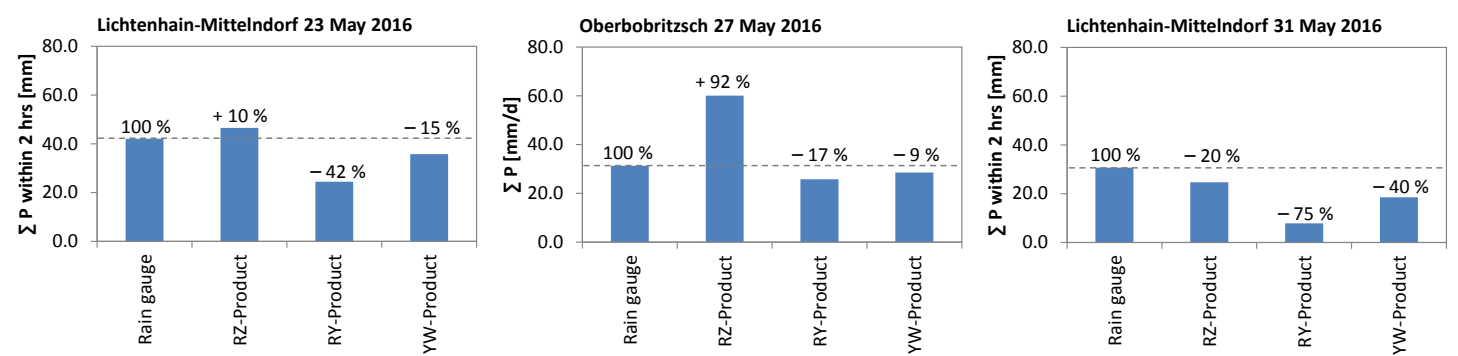

Figure 5. Comparison of radar precipitation data and rain gauge data at the rain gauge stations for the storm events on (a) 23 May, (b) 27 May, and (c) 31 May 2016. 
The comparison of rain gauge data with the uncalibrated RZ-product reveals an overestimation of precipitation for two storm events (Figure 5a,b). On 31 May 2016, the RZ-product underestimated the rain gauge data by $20 \%$ (Figure $5 \mathrm{c}$ ). In contrast, the quality-tested RY-product had the highest negative percentage in comparison to the rain gauge data for all three storm events (Figure 5a-c). It provided the lowest precipitation of all three 5-min radar precipitation data. As it was indicated in [11,19], $\mathrm{RY}$ is of high quality in cases of little to moderate precipitation, but not for storm events with high amounts of rainfall. The reprocessed YW-product also underestimates the rain gauge data, but to a much lower degree (Figure 5a-c). Overall, the figures vividly illustrate the effect of the adjustment by rain gauges on the YW-product in comparison to the quality-tested RY-product. However, looking at the RZ-product and YW-product on 31 May (Figure 5c), the RZ-product underestimated the rain gauge data to the lowest degree. This indicates that the uncalibrated RZ-product would have had the most convenient precipitation for 31 May. Considering all three storm events in turn, the overall deviations of the YW-product to rain gauge data are smaller than those of the RZ-product. In conclusion, the YW-product consistently provides the more reliable data in comparison to the rain gauge data for all three storm events. Therefore, the most realistic YW data were used as meteorological input for the soil erosion model E 3D to reconstruct the three muddy floods. In addition, the modeled erosion risk maps of the three storm events represent the most probable reconstructed erosion and deposition patterns generated by the muddy floods.

\subsubsection{The Storm Events by Radar Images}

The 5-min YW data were analyzed and categorized according to their precipitation intensity (Table 2). Figure 6 visualizes the three storm events over Saxony and their most intense 5 min on 23 May, 27 May, and 31 May 2016. It becomes obvious that these storm events differ in their spatial dimension and their distribution of heavy rain. Although the storm events have more or less the same very heavy intensity in $5 \mathrm{~min}$, their duration is different.
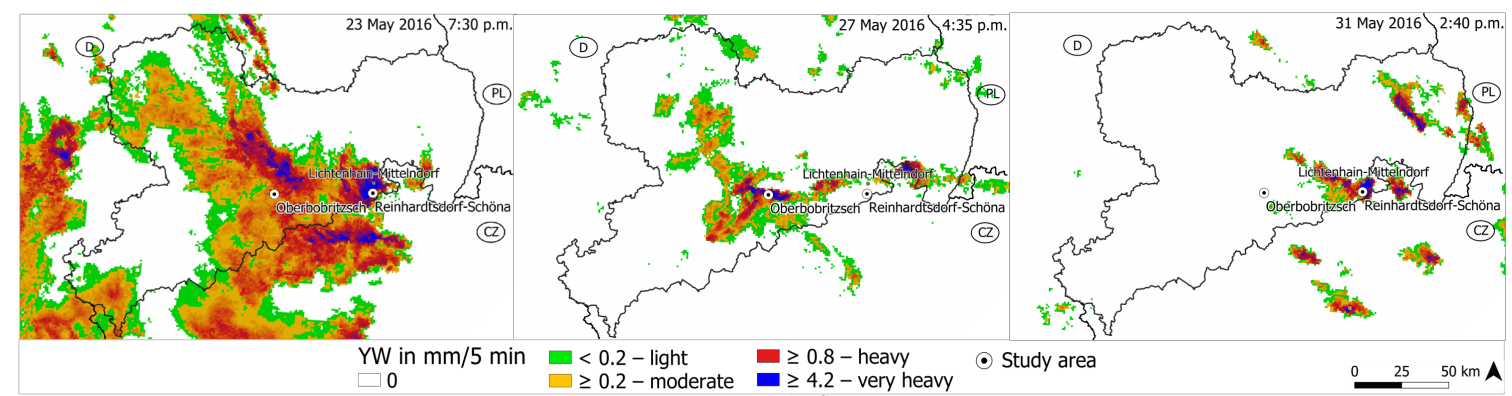

Figure 6. Visualization of radar precipitation data for the selected storm events over Saxony on (a) 23 May, (b) 27 May, and (c) 31 May 2016 (data basis: [20,21,35]).

Figure 6a illustrates one of the precipitation cells of a thunderstorm passing Reinhardtsdorf-Schöna in the evening hours on 23 May 2016. The most intense $5 \mathrm{~min}$ had a very heavy intensity of $8.9 \mathrm{~mm} / 5 \mathrm{~min}$. Within one hour, $16.1 \mathrm{~mm}$ rain fell, from which $10.7 \mathrm{~mm}$ fell within $10 \mathrm{~min}$. After a 15-min pause, another heavy rain cell passed the study area with a precipitation sum having fallen before within $5 \mathrm{~min}$. According to KOSTRA-DWD-2010R [36], this nearly two-hour storm event may occur in this region every year. However, looking at the duration of precipitation of $5 \mathrm{~min}$, this storm event had a return period of three years.

The situation is completely different for 27 May 2016 (Figure 6b). The 25-min storm event with $15 \mathrm{~min}$ of heavy to very heavy rain occurred over Oberbobritzsch in the late afternoon. Its most intense $5 \mathrm{~min}$ had a precipitation amount of $6.0 \mathrm{~mm}$. However, according to KOSTRA-DWD-2010R [36], this value for the duration of precipitation does not even have a return period of one year in this region. It is the same for the duration of precipitation of $20 \mathrm{~min}$. 
Figure $6 \mathrm{c}$ visualizes the storm event and its most intense 5 min over Reinhardtsdorf-Schöna on the afternoon on 31 May 2016. This event was shorter than that on 23 May 2016, but with more precipitation and longer heavy and very heavy rain. It rained heavily to very heavily for $40 \mathrm{~min}$. Within one hour, $28.5 \mathrm{~mm}$ of rain had fallen, corresponding to a return period in this region of three years [36]. Though, its most intense $5 \mathrm{~min}$ with $6.0 \mathrm{~mm}$ may occur every year. However, looking at the probably more suitable data for this storm event, the RZ-product (see Section 3.1.1), $54.2 \mathrm{~mm}$ of rain fell within one hour (see also [19]). This corresponds to a heavy rain event occurring every 100 years [36], and reveals a large discrepancy between both 5-min sets of radar precipitation data.

\subsubsection{The Radar Precipitation Forecasts}

The following analyses of the radar precipitation forecasting product RV are supposed to show whether a forecast would have been possible.

Figure 7 represents for all three storm events the precipitation sum $\left(\sum \mathrm{P}\right)$ of the RV-product for every forecast being generated $2 \mathrm{~h}$ before the most intense $5 \mathrm{~min}$ of the storm event.

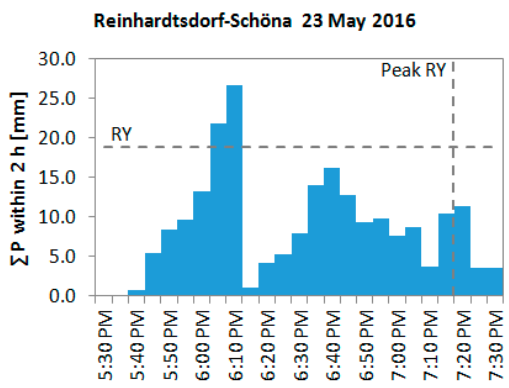

(a)

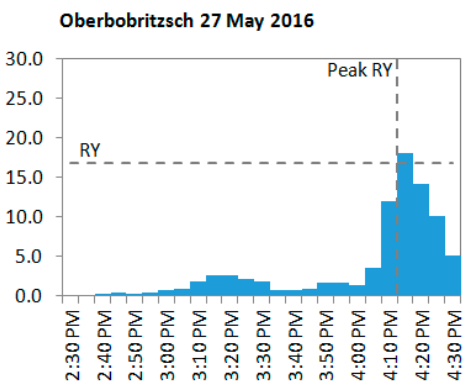

Generation time

(b)

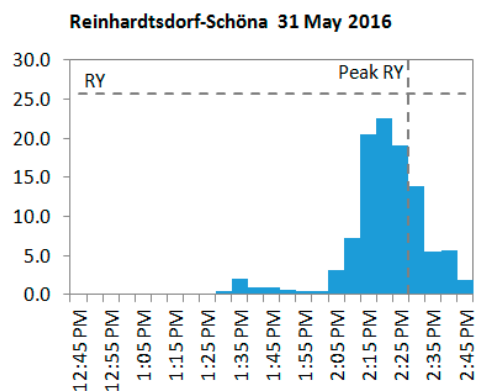

(c)

Figure 7. The RV product and its precipitation sum ( $\sum$ P) within $2 \mathrm{~h}$ for (a) 23 May 2016, (b) 27 May 2016, and (c) 31 May 2016. The horizontal dashed line marks the two-hour precipitation sum of the quality-tested RY-product, which is the basis for the RV-product. The vertical dashed line indicates the time of the most intense $5 \mathrm{~min}$ in the RY-data.

It is shown in Figure 7a that a precipitation event with a precipitation sum of almost $22 \mathrm{~mm}$ was already predicted one hour and $15 \mathrm{~min}$ (at 6:05 PM) before the actual storm event over Reinhardtsdorf-Schöna on 23 May 2016. After that forecast, the precipitation sum of the RY-product was not attained again by the RV-product. Looking at Figure $7 \mathrm{~b}$, it becomes obvious that the predicted precipitation sums were only attained with the actual storm event over Oberbobritzsch on 27 May 2016 at 4:15 PM. Figure 7c reveals a similar situation for Reinhardtsdorf-Schöna on 31 May 2016. The forecasted precipitation sums underestimate the RY-product completely.

Figure 8 demonstrates the maximum precipitation intensities $\left(\mathrm{P}_{\mathrm{i} \text { max }}\right)$ of the RV-products for all three storm events $2 \mathrm{~h}$ in advance. Additionally, the time of occurrence $\left(t_{\max }\right)$ is stated at which these maximum intensities are predicted.

Although the precipitation sums of the RY-product were underestimated by the forecast on 31 May, the forecasted precipitation intensities were attained $15 \mathrm{~min}$ in advance (Figure 8c). Therefore, a forecast of the muddy flood would have been possible $15 \mathrm{~min}$ in advance on 31 May 2016. Since radar detects precipitation earlier than the rain gauge station on the ground [19,83-85], this time buffer increases a possible warning time. The intensities predicted for 7:10 PM at 6:05 PM on 23 May 2016 exceeded the intensities of the actual RY data (Figure 8a). However, all the other predicted intensities were below the actual RY intensities. Therefore, a forecast would have been possible on 23 May at 6:05 PM and 6:10 PM with $75 \mathrm{~min}$ in advance, plus the time buffer due to radar measurements. Looking at Figure 8b, the actual RY intensity was not even attained by the predicted intensities at the time of the storm event on 27 May 2016. Consequently, the forecast of this storm event was not modeled by E 3D. This also 
means that although the RY-product is the basis for the radar precipitation forecasting product RV, its sums and intensities were not attained. Overall, as seen in Section 3.1.1, the precipitation sums and intensities of the YW-product are significantly higher than those of the RY-product. Thereby, the YW-product would underestimate the forecasts of the RV-product even more than the RY-product.

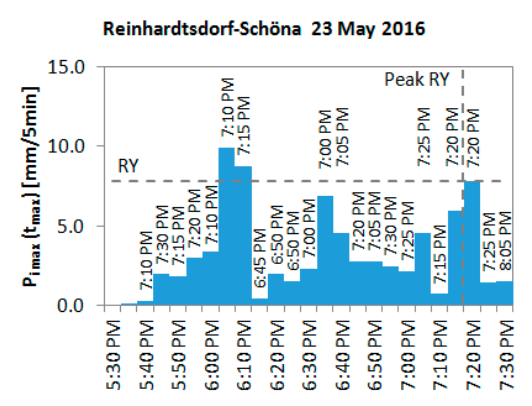

(a)

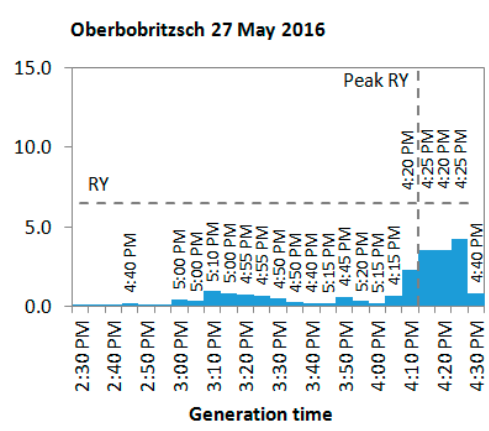

(b)

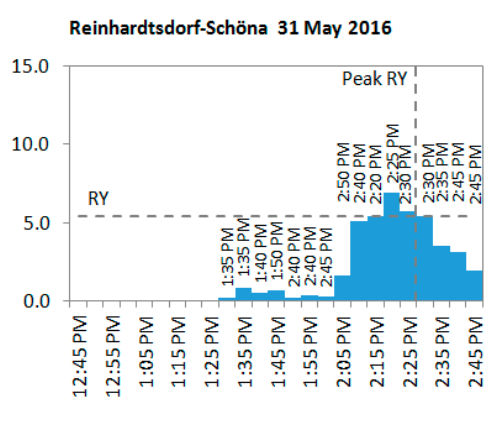

(c)

Figure 8. The RV-product with its maximum precipitation intensity $\left(P_{i \max }\right)$ at its time of occurrence $\left(t_{\max }\right)$ within the two-hour forecast for (a) 23 May 2016, (b) 27 May 2016, and (c) 31 May 2016. The horizontal dashed line marks the respective maximum intensity in the RY data, the vertical line marks the time at which this intensity actually occurred.

\subsection{High-Resolution Physically-Based Erosion Modeling Using EROSION 3D}

\subsubsection{Reconstruction and Qualitative Validation of the Muddy Floods}

The following figures firstly describe the sediment budget of the three reconstructed muddy floods as erosion risk maps created by the soil erosion model E 3D, and secondly the corresponding orthophoto as a result of UAV monitoring. The high-resolution physically-based erosion modeling was performed with the 5-min radar precipitation YW-product. By means of the orthophoto acquired after the muddy floods occurred, the model results could be qualitatively validated.

Figure 9 visualizes the modeled erosion risk maps with the YW-product of Reinhardtsdorf-Schöna for 23 May 2016 and 31 May 2016 and the corresponding orthophoto. Red to yellow colors indicate loss, and light green to dark green colors indicate deposition of the soil particles on the underlying land use. Both maps (Figure 9a,b) reproduce the main flow routes of sediment-laden water on the maize field, as it is evidenced in the orthophoto (Figure 9c). The effect of tillage direction on the flow direction of the muddy runoff, which was parallel to the slope at that time, is not verified in the orthophoto. Therefore, the tillage direction was not modeled with E 3D. Furthermore, the orthophoto matches the course of the muddy runoff being modeled by the flow path model and the determined soil parameters of E 3D. The modeled muddy runoff from the field entered the narrow meadow strip in front of the forest and the steeply sloping forest. Moreover, the sediment source areas are visible and identifiable. Overall, the E 3D model results could be satisfactorily validated in their spatial context.

The modeled erosion risk maps (Figure 9a,b) show the main flow routes of muddy runoff in the forest and its deposition on the railway line and the meadows behind the tracks. The deposition amounts to a 200-m length along the tracks. Figure $9 a$ and $9 b$ describe another deposition on the railway line, at a culvert draining excessive waters. However, E 3D cannot model culverts, and consequently, the model incorrectly resulted in deposition on the railway line at this point. Additionally, the deposition modeled on the meadows was not reported [8]. This is because the low height of the railway tracks cannot be modeled with E 3D. Finally, Figure $9 \mathrm{~b}$ reveals another sedimentation in the northern forest, which did not reach the railway line. This is evidenced by a picture resulting from an inspection of the study area (Figure 10). However, this picture was taken after the first muddy flood happened, on 29 May 2016. However, Figure 9a does not describe such a long deposition in the northern forest. 
It indicates that the amounts of precipitation of the YW-product for 23 May 2016 were presumably a little too low to result in a longer downhill deposition.

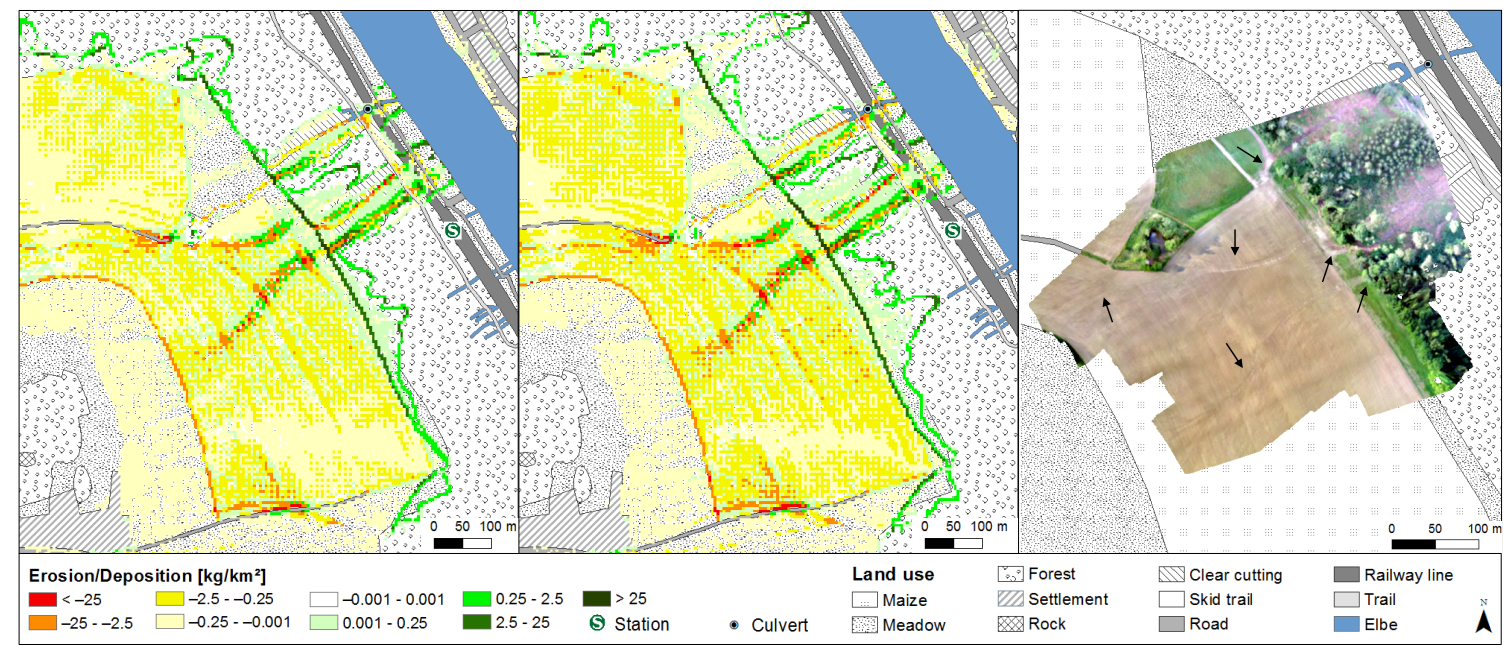

Figure 9. The erosion risk maps with the YW-product for (a) 23 May 2016 and (b) 31 May 2016, and (c) UAV acquired orthophoto of Reinhardtsdorf-Schöna.

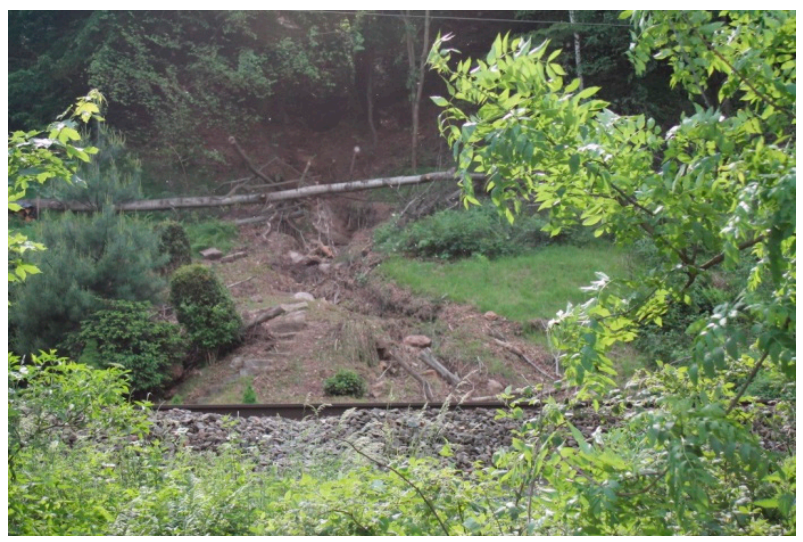

Figure 10. Another deposition of mud, tree trunks, and stones behind the railway lines, photographed on 29 May 2016 [86].

Figure 11 describes the modeled erosion risk map of Oberbobritzsch for 27 May 2016 and the corresponding orthophoto. Erosion patterns particularly occurred on the peas and maize field. These erosion patterns predominantly indicate sheet erosion phenomena. The modeled linear erosion gully is evidenced in the orthophoto. Moreover, the modeled deposition is located north of the district road, directly after the muddy runoff has left the winter cereal field (Figure 11a). However, the muddy runoff flowed down the district road to Oberbobritzsch in a northeastern direction [10].

\subsubsection{Forecast of the Muddy Floods}

Due to the preceding analyses of the radar precipitation forecasting product (see Section 3.1.3), Figure 12a,b visualize the forecasted erosion risk map and the corresponding surface runoff map modeled with the historical real-time RV-product at 6:05 PM for 23 May 2016. The modeled erosion risk map (Figure 12a) visualizes the aforementioned erosion and deposition patterns (Figure 9a,b). It vividly shows that with these forecasted radar precipitation amounts of the RV-product, which are similar to the RY data, the corresponding erosion and deposition patterns of the YW-product can be obtained. The modeled surface runoff amounts up to almost $16 \mathrm{~m}^{3} / \mathrm{m}$ at the entry point of runoff on the railway line. 


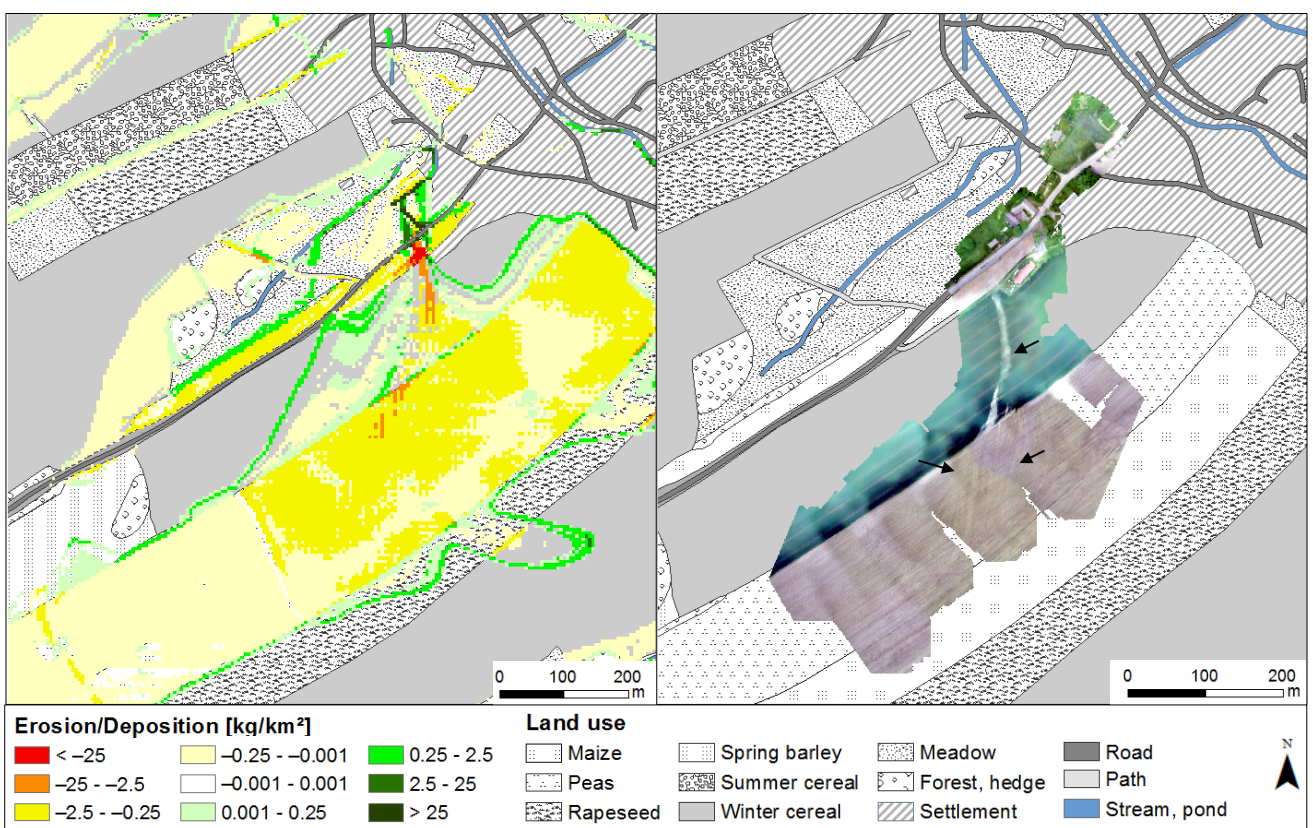

Figure 11. (a) The erosion risk map with the YW-product for 27 May 2016 and (b) the UAV acquired orthophoto of Oberbobritzsch.

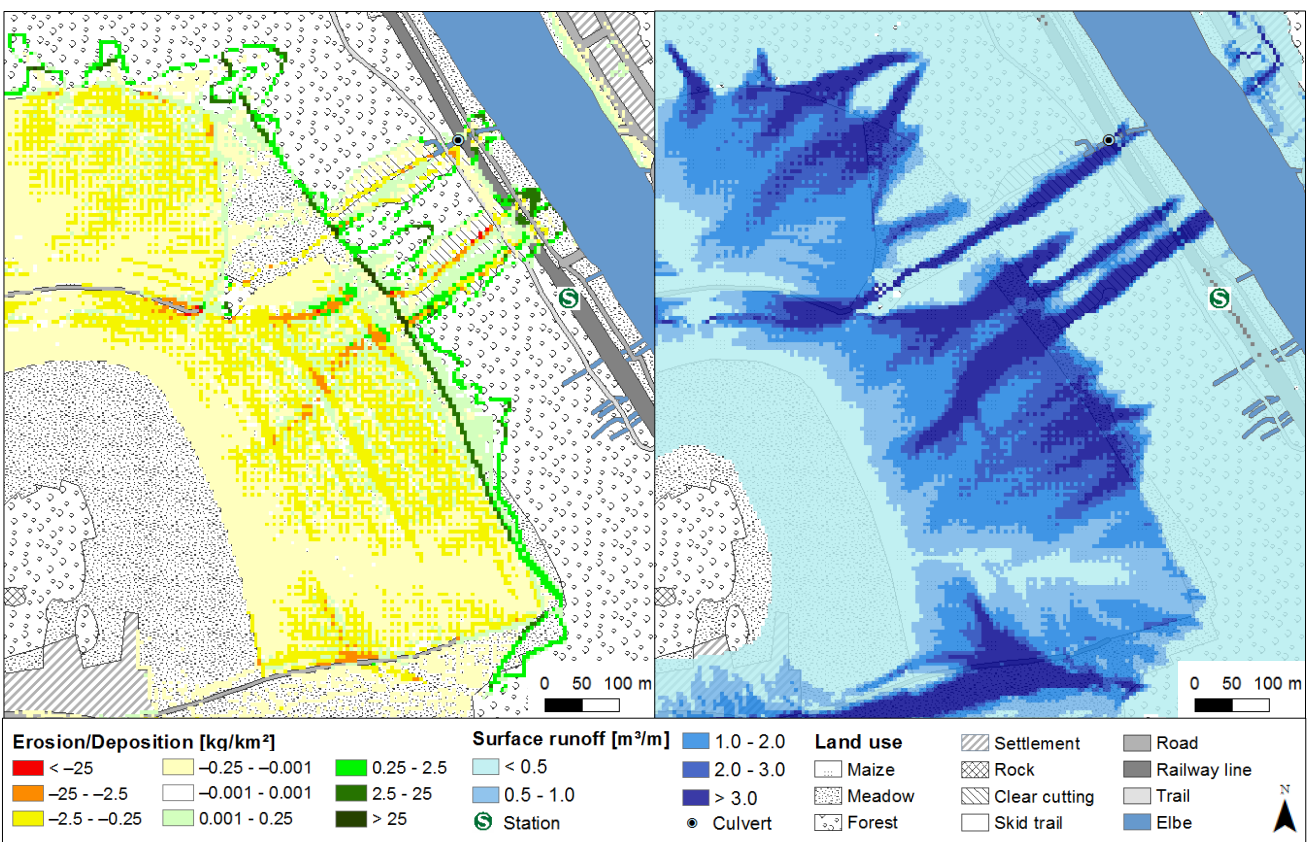

Figure 12. (a) The erosion risk map and (b) corresponding surface runoff map with the RV-product at 6:05 PM for 23 May 2016.

Figure 13a,b visualize the forecasted erosion risk map and the corresponding surface runoff map modeled with the historical real-time RV-product at 12:15 PM for 27 May 2016. They reflect the same aforementioned facts. Due to the lower precipitation amounts of the RV-product, the aforementioned erosion and deposition patterns appear weaker. The modeled runoff amounts up to $0.1 \mathrm{~m}^{3} / \mathrm{m}$ at the entry point of runoff on the railway line. 


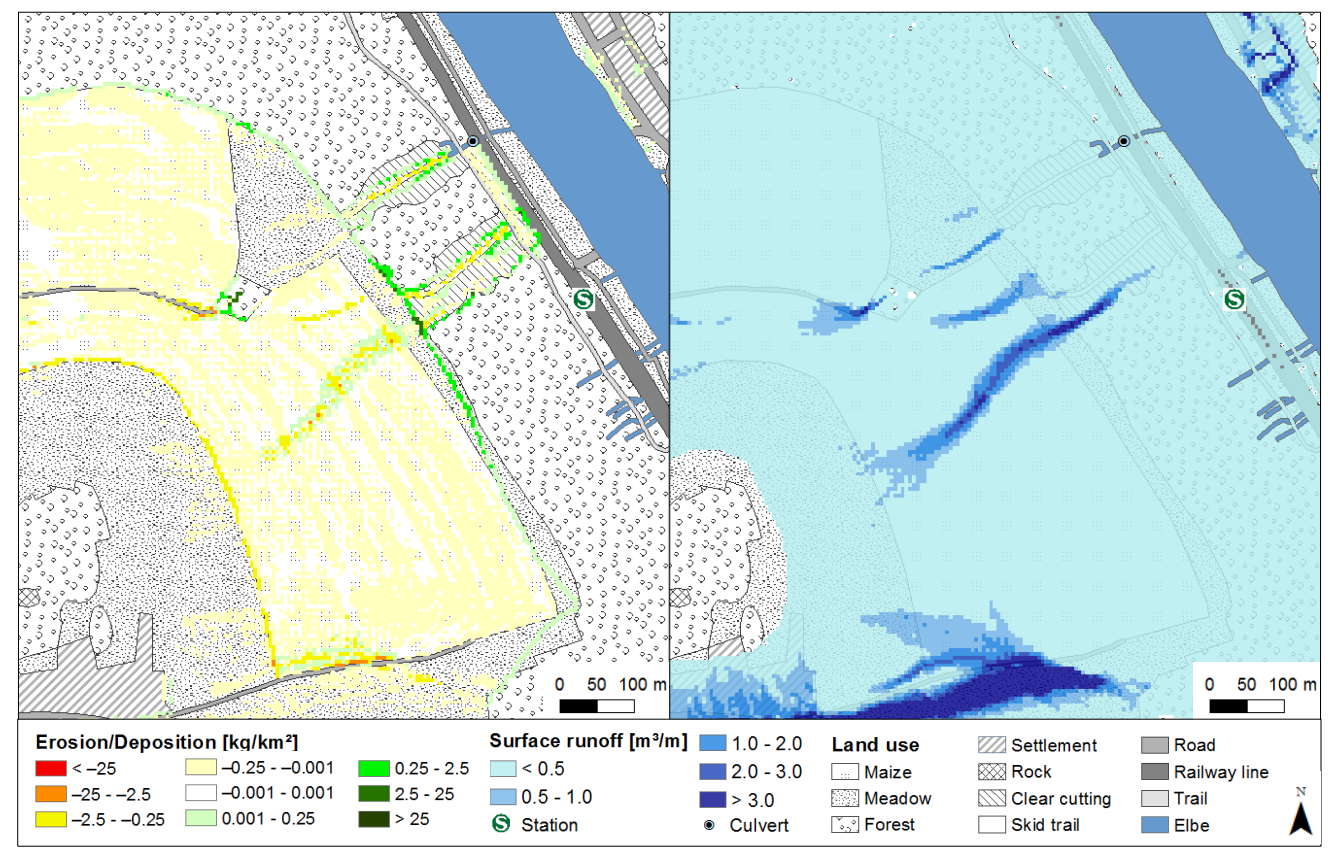

Figure 13. (a) The erosion risk map and (b) corresponding surface runoff map with the RV-product at 12:15 PM for 31 May 2016.

\section{Discussion}

The comparison of the 5-min radar precipitation data and rain gauge data for all three storm events was performed in order to select the most suitable area-wide precipitation product for the study areas and the most probable model results. The analysis revealed that the quality-tested RY-product provides the lowest amounts of precipitation (Figure $5 \mathrm{a}-\mathrm{c}$ ). Although it is currently the best 5 -min radar precipitation product resulting from the only processing of radar data, the analysis indicates again its unsuitability in cases of high amounts of precipitation [11,19]. The precipitation data of the unadjusted RZ-product show for all three storm events overall greater deviations from the rain gauge data than the YW-product. However, looking at the storm event on 31 May 2016 (Figure 5c), the RZ-product underestimates the rain gauge data to the lowest degree. Therefore, it indicates most likely the most convenient precipitation for 31 May 2016. However, after assessing the RZ-products and YW-products according to the KOSTRA-DWD-2010R, the discrepancy between a heavy rain event occurring every 100 years (RZ) and one occurring every three years (YW) remains large. Consequently, the YW-product consistently provides the more reliable data in comparison to the rain gauge data for the data series of three storm events. In conclusion, it was chosen as the meteorological input data for the soil erosion model E 3D to reconstruct the muddy floods.

According to the analyses of the real-time radar precipitation forecasting product RV, it becomes obvious that the precipitation sums and intensities of the RY-product were rarely matched over the lead time of two hours. However, with matching, a forecast of the storm event and a potential muddy flood would be possible. Two of the storm events were predicted, while one could not be predict. The evening storm on 23 May 2016 would have been forecasted with a lead time of $75 \mathrm{~min}$ plus the time buffer due to radar measurement. On 31 May 2016, a forecast of a potential muddy flood would have been also possible $15 \mathrm{~min}$ in advance plus the time buffer. Due to the missing matches of the forecasted precipitation amounts and intensities of the RV-product with actual RY data on 27 May 2016, a forecast would have been impossible. These missing matches between real-time radar precipitation forecasts and actual real-time radar precipitation data may arise from the currently available procedures of radar tracking being only modules of extrapolation. Thus, the development of precipitation intensities of rainfall cells in forecasting procedures is not considered yet [30]. Overall, the YW-product, with its 
higher amounts of precipitation, would be even more underestimated by the forecasts of the RV-product than those of the RY-product.

The reconstructed erosion patterns on the erosion risk maps modeled by $\mathrm{E} 3 \mathrm{D}$ are consistent with the UAV-based orthophoto for all three muddy floods. Thereby, the model results could be qualitatively validated in their spatial context. The model results for 23 and 31 May 2016 indicate soil deposition on the railway line over a length of $200 \mathrm{~m}$ (Figure 9a,b). As reported by Hebenstreit [87], the deposition was longer: up to $400 \mathrm{~m}$ on 23 May 2016 and $500 \mathrm{~m}$ on 31 May 2016. Although E 3D cannot model culverts and despite the low height differences between the railway track and track bed, the deposition of the soil particles was satisfactorily simulated. Therefore, the entry point of sediment is locatable. The incorrectly located deposition from the muddy runoff for the modeled muddy flood on 27 May 2016 (Figure 11a) is a result of the coarse resolution of the DTM. The low height differences between the arable field and road could not be adequately reproduced by a DTM with a resolution of $5 \mathrm{~m}$.

The forecasted erosion risk maps modeled by E 3D for 23 May 2016 and 31 May 2016 vividly show that with the radar precipitation amounts of the RV-product, which are similar to the RY data, the similar erosion and deposition patterns of the YW-product can be obtained. Additionally, with the corresponding surface runoff maps, the entry point of runoff of a potential muddy flood could be localized.

\section{Conclusions}

The analyzed storm events differ in their distribution of heavy rain and spatial dimension. According to the KOSTRA-DWD-2010R [36], they can occur every year in these regions according to the YW-product. In the case of the storm event on 31 May 2016, the return period amounts to 3 years. Therefore, the risk for the development of potential muddy floods on sparsely vegetated arable fields exists every year in the investigated areas. Especially, it increases in the case of the silty soils of the study areas tending to soil surface sealing and crusting.

The modeling of the three muddy floods by E 3D and the new YW-product resulted in a satisfactory reconstruction according to the monitored and qualitatively validated erosion and deposition patterns. This reconstruction and the analyses of all three 5-min radar precipitation data (see Section 3.1.1) indicate that adjusted radar products are currently more suitable for storm events than those resulting from the only processing of radar data. Thereby, the more convenient precipitation data of the RZ-product for 31 May 2016 were initially neglected due to the decision for a consistent data series of three storm events. However, this needs to be taken into account for a potential further development of 5-min radar precipitation data. Although the YW-product pertains to a reprocessed dataset, its precipitation intensities are closer to reality due to quasi-gauge adjustment. Presently, the DWD provides qualitatively improved RZ data and RY data due to the conversion to new dual-polarization radar systems $[88,89]$. Thereby, the analysis and estimation of radar precipitation amounts without the adjustment to rain gauge data should be improved. Moreover, the precipitation sums and intensities of the forecasted RV-product rarely attained the actual precipitation data of the RY-product over the lead time of two hours. Here, the DWD is currently testing a new nowcasting-system with the aforementioned dual-pol data, which is the basis for a new RV-product, and new tracking and forecasting procedures [90].

The forecasts of two muddy floods could be modeled by means of E 3D and high-resolution radar precipitation forecasts. Accordingly, the method of a historical forecast modeling of muddy floods in ungauged catchments of agricultural landscapes works satisfactorily. Therefore, as ungauged catchments have no accurate runoff and sediment budget data due to missing measurement stations, the prediction of muddy floods by means of $\mathrm{E} 3 \mathrm{D}$ and its modeling of soil erosion on the basis of physical processes seems to be a promising method. Naturally, the data series of three muddy floods should be extended to more forecasts of muddy floods for statistical analysis and statements. Furthermore, with forecasted erosion risk and surface runoff maps, the localization of sediment and runoff entry 
points is possible. Thereby, prevention and mitigation measures such as emergency measures, retention ponds, and dams could be located.

However, for the development of a real-time muddy flood early warning system in order to be a useful tool for decision makers in a possible disaster situation, future research should firstly focus on the derivation of soil parameters from other databases of rainfall simulation experiments. With the appropriate input parameters, it will become possible to extend the application of $\mathrm{E} 3 \mathrm{D}$ and its simulation of soil erosion in principle to every catchment. Moreover, for the future development of E 3D, the modeling of culverts and small topographic changes must be taken into account, as they are typical for railway lines. Furthermore, future research should also tackle the automated estimation of the E 3D model parameter 'cover' from satellite data. At present, there exists an estimation panel in the parameter catalogue to assess this soil parameter non-automatically. As the NDVI was tested successfully as a possible method to estimate the cover of agricultural fields, it seems to be a promising tool for automatic processing. Subsequently, the development of automated process chains and interfaces should be realized. Besides the development of a real-time muddy flood early warning system, it is also conceivable to generate a real-time muddy flood monitoring and simulating system for decision makers in sustainable watershed management, land-use planning, and politics. Overall, these potential developments should also be tested with the newly provided 5-min radar precipitation data and forecasts of the DWD.

Author Contributions: Conceptualization, M.S., J.S., P.H.; methodology, M.S., A.K., P.H., J.S., F.B., S.L.; software, A.B., M.S., A.K., P.H., F.B., S.L.; validation, M.S., A.K., P.H., S.L.; formal analysis, M.S., A.K., P.H., S.L.; investigation, A.B., M.S., A.K., P.H., S.L.; resources, M.S., A.K., P.H., J.S., F.B., S.L.; data curation, X.X.; writing-original draft preparation, P.H., M.S., J.S.; writing-review and editing, P.H.; visualization, P.H., M.S., A.K., S.L.; supervision, M.S., J.S.; project administration, M.S., J.S.; funding acquisition, M.S., A.K., J.S.

Funding: This research was only possible due to the financial support of the European Social Fund in the Free State of Saxony (project: doctorate).

Acknowledgments: This study was only possible due to the provision of the RZ, RY, and RV products by Tanja Winterrath of the DWD. The authors wish to thank her and Mario Hafer of the DWD for his GIS expertise of the RADOLAN products. Moreover, the authors wish to thank Felix Linde of the ZALF e. V. for his initial support on weather radar data processing. Furthermore, the authors would like to thank the team of Wradlib for their instructive help with Wradlib. Overall, we want to thank the reviewers for their valuable comments on the manuscript.

Conflicts of Interest: The authors declare no conflict of interest. The funders had no role in the design of the study; in the collection, analyses, or interpretation of data; in the writing of the manuscript; or in the decision to publish the results.

\section{Abbreviations}

DLM

DTM

DWD

E 3D

GIS

KOSTRA-DWD-2010R

METVER

NDVI

RADKLIM

RADOLAN
Digital Landscape Model

Digital Terrain Model

German term, abbreviated from Deutscher Wetterdienst meaning German

Meteorological Service

EROSION 3D Soil Erosion Model

Geographic Information Systems

German term, abbreviated from KOordinierte

STarkniederschlagsRegionalisierung und -Auswertung des DWD meaning coordinated regionalization and analysis of heavy precipitation by the DWD German term, abbreviated from METeorologisches VERdunstungsmodell, meaning meteorological evaporation model

Normalized Difference Vegetation Index

German term, abbreviated from RADarKLIMatologie, meaning

radar climatology

German term, abbreviated from RADar-OnLine-ANeichung meaning radar online adjustment 


\section{RADVOR}

SfM

UAV

USLE
German term, abbreviated from RADar-NiederschlagsVORhersage, meaning radar precipitation forecast

Structure from Motion

Unmanned Aerial Vehicle

Universal Soil Loss Equation

\section{References}

1. Boardman, J. A short history of muddy floods. Land Degrad. Dev. 2010, 21, 303-309. [CrossRef]

2. Boardman, J.; Vandaele, K.; Evans, R.; Foster, I. Off-site impacts of soil erosion and runoff: Why connectivity is more important than erosion rates. Soil Use Manag. 2019, 35, 245-256. [CrossRef]

3. Eltner, A.; Baumgart, P.; Maas, H.-G.; Faust, D. Multi-temporal UAV data for automatic measurement of rill and interrill erosion on loess soil. Earth Surf. Process. Landf. 2015, 40, 741-755. [CrossRef]

4. Blume, H.-P.; Brümmer, G.W.; Fleige, H.; Horn, R.; Kandeler, E.; Kögel-Knabner, I.; Kretzschmar, R.; Stahr, K.; Wilke, B.-M. Scheffer/Schachtschabel Soil Science, 1st ed.; Springer: Berlin/Heidelberg, Germany, 2016.

5. Ad-hoc-Arbeitsgruppe Boden der Staatlichen Geologischen Dienste und der Bundesanstalt für Geowissenschaften und Rohstoffe. Bodenkundliche Kartieranleitung, 5th ed.; E. Schweizerbart'sche Verlagsbuchhandlung (Nägele und Obermiller): Stuttgart, Germany, 2005; pp. 1-438.

6. Ziese, M.; Junghänel, T.; Becker, A. Andauernde Großwetterlage Tief Mitteleuropa Entfaltet Ihr Unwetterpotential mit Starken Gewittern und Massiven Schadensgeschehen in Deutschland. Available online: https://www.dwd.de/DE/leistungen/besondereereignisse/niederschlag/20160603_starkregen_mai2016_meldung.html (accessed on 18 July 2019).

7. Bronstert, A.; Agarwal, A.; Boessenkool, B.; Fischer, M.; Heistermann, M.; Köhn-Reich, L.; Moran, T.; Wendi, D. Die Sturzflut von Braunsbach am 29. Mai 2016-Entstehung, Ablauf und Schäden eines "Jahrhundertereignisses". Teil 1: Meteorologische und hydrologische Analyse. The Braunsbach Flashflood of Mai 29th, 2016-Origin, Pathways and Impacts of an Extreme Hydro-Meteorological Event. Part 1: Meteorological and Hydrological Analysis. Hydrol. Wasserbewirtsch. 2017, 61, 150-162. [CrossRef]

8. earth-chronicles.com. A Landslide Disrupted Rail Service between Dresden and Prague. Available online: http://earth-chronicles.com/natural-catastrophe/a-landslide-disrupted-rail-service-between-dresdenand-prague.html (accessed on 14 September 2016).

9. Radio Leipzig. Unwetter Sorgt für Schäden in Sächsischer Schweiz. Available online: www.radioleipzig.de/ beitrag/unwetter-sorgt-fuer-schaeden-in-saechsischer-schweiz-230485 (accessed on 23 July 2018).

10. TAG24.de. Heftiges Unwetter löst Schlammlawine aus. Available online: https://www.tag24.de/nachrichten/ freiberg-mittelsachsen-unwetter-tobt-ueber-sachsen-schlammlawine-69045 (accessed on 23 July 2019).

11. DWA-Themen. Niederschlagserfassung Durch Radar und Anwendung in Der Wasserwirtschaft-T2/2017; Deutsche Vereinigung für Wasserwirtschaft, Abwasser und Abfall e. V.: Hennef, Germany, 2017; pp. 1-99.

12. Fischer, F.K.; Winterrath, T.; Junghänel, T.; Walawender, E.; Auerswald, K. Mean annual precipitation erosivity (R factor) based on RADKLIM Version 2017.002. 2019. [CrossRef]

13. Fischer, F.; Hauck, J.; Brandhuber, R.; Weigl, E.; Maier, H.; Auerswald, K. Spatio-temporal variability of erosivity estimated from highly resolved and adjusted radar rain data. Agric. For. Meteorol. 2016, 223, 72-80. [CrossRef]

14. Fischer, F.K.; Kistler, M.; Brandhuber, R.; Maier, H.; Treisch, M.; Auerswald, K. Validation of official erosion modelling based on high-resolution radar rain data by aerial photo erosion classification. Earth Surf. Process. Landf. 2018, 43, 187-194. [CrossRef]

15. Fischer, F.K.; Winterrath, T.; Auerswald, K. Temporal- and spatial-scale and positional effects on rain erosivity derived from point-scale and contiguous rain data. Hydrol. Earth Syst. Sci. 2018, 22, 6505-6518. [CrossRef]

16. Winterrath, T.; Brendel, C.; Hafer, M.; Junghänel, T.; Klameth, A.; Lengfeld, K.; Walawender, E.; Weigl, E.; Becker, A. RADKLIM Version 2017.002: Reprocessed gauge-adjusted radar data, one-hour precipitation sums (RW). 2018. [CrossRef]

17. Schmidt, J. Entwicklung und Anwendung eines physikalisch begründeten Simulationsmodells für die Erosion geneigter, landwirtschaftlicher Nutzflächen. Berl. Geogr. Abh. 1996, 61, 1-148. 
18. Deumlich, D. Nutzung Von RADOLAN-Daten Zur Retrospektiven Analyse Von Erosionsereignissen. In Proceedings of the Berichte der DBG: Böden verstehen-böden nutzen-böden fit machen, Berlin, Germany, 3-9 September 2011; Available online: http://eprints.dbges.de/609/ (accessed on 21 July 2019).

19. Hänsel, P.; Kaiser, A.; Buchholz, A.; Böttcher, F.; Langel, S.; Schmidt, J.; Schindewolf, M. Mud flow reconstruction by means of physical erosion modeling, high-resolution radar-based precipitation data and UAV monitoring. Geosciences 2018, 8, 21. [CrossRef]

20. Winterrath, T.; Brendel, C.; Hafer, M.; Junghänel, T.; Klameth, A.; Lengfeld, K.; Walawender, E.; Weigl, E.; Becker, A. RADKLIM Version 2017.002: Reprocessed quasi gauge-adjusted radar data, 5-minute precipitation sums (YW). 2018. [CrossRef]

21. OSM Boundaries Map 4.4.6. Wambachers-OSM. Available online: https://wambachers-osm.website/ boundaries/ (accessed on 28 September 2018).

22. DWD Climate Data Center (CDC): Multi-Annual Station Means for the Climate Normal Reference Period 1981-2010, for Current Station Location and for Reference Station Location. Available online: https:/opendata. dwd.de/climate_environment/CDC/observations_germany/climate/multi_annual/mean_81-10/ (accessed on 21 July 2019).

23. BK 50 2012: Sächsisches Landesamt für Umwelt, Landwirtschaft und Geologie. Available online: https: //www.umwelt.sachsen.de/umwelt/boden/27787.htm (accessed on 21 July 2018).

24. DWD Climate Data Center (CDC): Historical Daily Precipitation Observations for Germany; Version v007 (Daily Precipitation Data). 2019. Available online: https://opendata.dwd.de/climate_environment/CDC/ observations_germany/climate/daily/more_precip/historical/ (accessed on 21 July 2019).

25. DWD RADOLAN Produktübersicht. Available online: https://www.dwd.de/DE/leistungen/radolan/radolan. html (accessed on 16 July 2019).

26. DWD Erhöhung Der Zeitlichen Taktrate Der Nationalen Standard-Aneichung (RW) Von Einer Stunde Auf Zehn Minuten. RADOLAN-Info Nr. 47. Available online: https://www.dwd.de/DE/leistungen/radolan/ radolan_info/radolan_info_nr_47.pdf?__blob=publicationFile\&v=2 (accessed on 11 July 2019).

27. DWD RADKLIM. Erstellung Einer Radargestützten Hochaufgelösten Niederschlagsklimatologie für Deutschland zur Auswertung Der Rezenten Änderungen Des Extremverhaltens Von Niederschlag. Beschreibung des Kompositformats und Der Verschiedenen Reprozessierungsläufe; Version 1.0. Available online: https://www.dwd.de/EN/ourservices/radarklimatologie/format_description_in_german.pdf?_blob= publicationFile\&v=2 (accessed on 16 July 2019).

28. DWD RADVOR-Kurzbeschreibung. Available online: https://www.dwd.de/EN/ourservices/radvor/radvor. html (accessed on 15 July 2019).

29. DWD Operationalisierung von RADVOR(RY) am 25.11.2015, 11:30 MEZ, erfolgt. RADVOR-Info Nr. 18. Available online: https://www.dwd.de/DE/leistungen/radvor/radvor_info/radvor_op_info_nr_18.pdf? blob=publicationFile\&v=2 (accessed on 22 July 2019).

30. DWD RADVOR-OP Kurzbeschreibung. Available online: https://www.dwd.de/DE/fachnutzer/ wasserwirtschaft/unsere_leistungen/radarniederschlagsprodukte/radvor_opkurzbeschreibung_pdf.html (accessed on 17 July 2019).

31. Open Data Server DWD 2019. Data Source: Deutscher Wetterdienst. Radolan. Available online: https: //opendata.dwd.de/weather/radar/radolan/ (accessed on 11 July 2019).

32. DWD RADOLAN/RADVOR. Hoch aufgelöste Niederschlagsanalyse und -vorhersage auf der Basis quantitativer Radar- und Ombrometerdaten für grenzüberschreitende Fluss-Einzugsgebiete von Deutschland im Echtzeitbetrieb Beschreibung des Kompositformats; Version 2.4.5. Available online: https://www.dwd.de/ DE/leistungen/radolan/radolan.html (accessed on 15 July 2019).

33. Heistermann, M.; Jacobi, S.; Pfaff, T. Technical Note: An open source library for processing weather radar data (wradlib). Hydrol. Earth Syst. Sci. 2013, 17, 863-871. [CrossRef]

34. DWD Wetterlexikon. Available online: www.dwd.de/lexikon (accessed on 22 July 2019).

35. QGIS 2018. QGIS Version 3.0.1-Girona 64 bit. Available online: https://www.qgis.org (accessed on 10 April 2018).

36. DWD Climate Data Center (CDC): Grids of Return Periods of Heavy Precipitation (Design Precipitation) over Germany (KOSTRA-DWD); Version 2010R. Available online: https:/opendata.dwd.de/climate_ environment/CDC/grids_germany/return_periods/precipitation/KOSTRA/KOSTRA_DWD_2010R/ (accessed on 12 July 2019). 
37. DWD Climate Data Center (CDC): Historical 1 Minute Precipitation Observations for Germany; Version v007. 2019. Available online: https://opendata.dwd.de/climate_environment/CDC/observations_germany/ climate/1_minute/precipitation/historical/2016/ (accessed on 11 July 2019).

38. DWD Climate Data Center (CDC): Historical Daily Precipitation Observations for Germany; Version v007 (Every Minute Precipitation Data). 2019. Available online: https://opendata.dwd.de/climate_environment/ CDC/observations_germany/climate/daily/more_precip/historical/ (accessed on 21 July 2019).

39. Von Werner, M. Erosion-3D Benutzerhandbuch; Version 3.0.; Michael von Werner: Berlin, Germany, 2002; pp. 1-82.

40. Klik, A.; Zartl, A.S.; Hebel, B.; Schmidt, J. Comparing RUSLE, EROSION 2D/3D, and WEPP Soil Loss Calculations with Four Years of Observed Data. In Proceedings of the ASAE, Annual International Meeting, Orlando, FL, USA, 11-16 July 1998. ASAE No. 982055.

41. Jetten, V.; de Roo, A.; Favis-Mortlock, D. Evaluation of field-scale and catchment-scale soil erosion models. Catena 1999, 37, 521-541. [CrossRef]

42. Schmidt, J.; von Werner, M.; Michael, A. Application of the EROSION 3D Model to the Catsop Watershed, The Netherlands. Catena 1999, 37, 449-456. [CrossRef]

43. Hebel, B. Validierung numerischer Erosionsmodelle in Einzelhang und Einzugsgebietsdimension. Phys. Baseler Beitr. Zur Phys. 2003, 32, 1-181.

44. Michael, A.; Schmidt, J.; Enke, W.; Deutschländer, T.; Malitz, G. Impact of expected increase in precipitation intensities on soil loss-Results of comparative model simulations. Catena 2005, 61, 155-164. [CrossRef]

45. Schob, A.; Schmidt, J.; Tenholtern, R. Derivation of site-related measures to minimise soil erosion on the watershed scale in the Saxonian loess belt using the model EROSION 3D. Catena 2006, 68, 153-160. [CrossRef]

46. Schilde, M. Modelling Soil Erosion in the Zhifanggou-Watershed on the Chinese Loess Plateau using EROSION 2/3D; TU Bergakademie Freiberg: Freiberg, Germany, 2008; 79p.

47. Seidel, N. Untersuchung der Wirkung Verschiedener Landnutzungen auf Oberflächenabfluss und Bodenerosion mit einem Simulationsmodell. Ph.D. Thesis, TU Bergakademie Freiberg, Freiberg, Germany, 2008.

48. Schindewolf, M.; Schmidt, W. Validierung EROSION 3D—Prüfung und Validierung des neu entwickelten Oberflächenabflussmoduls des Modells EROSION 3D im Zusammenhang mit Maßnahmen des vorsorgenden Hochwasserschutzes auf landwirtschaftlich genutzten Flächen. Schri. Landesamtes Umwelt Landwirtsch. Geol. 2009, 15, 1-121. Available online: https://nbn-resolving.org/urn:nbn:de:bsz:14-ds-1244617738468-42743 (accessed on 23 July 2019).

49. Schindewolf, M. Prozessbasierte Modellierung von Erosion, Deposition und Partikelgebundenem Nährund Schadstofftransport in der Einzugsgebiet- und Regionalskala. Ph.D. Thesis, TU Bergakademie Freiberg, Freiberg, Germany, 2012.

50. Steinz, A. Prozessbasierte Ermittlung des Jährlichen Partikelgebundenen Schwermetallaustrages im Einzugsgebiet der Mulde. Master's Thesis, TU Bergakademie Freiberg, Freiberg, Germany, 2014.

51. Starkloff, T.; Stolte, J. Applied comparison of the erosion risk models EROSION 3D and LISEM for a small catchment in Norway. Catena 2014, 118, 154-167. [CrossRef]

52. Schindewolf, M.; Kaiser, A.; Buchholz, A.; Schmidt, J. Development of a flash flood warning system based on real-time radar data and process-based erosion modelling. In EGU General Assembly Conference Abstracts; EGU2017-18057; EGU General Assembly: Vienna, Austria, 2017; Volume 19.

53. LfUG. Bodenerosionsmessprogramm Sachsen-Auswertung der Beregnungsversuche 1-28 vom 04.-31.10.1993; LfUG: Freiberg, Germany, 1994.

54. LfUG. Bodenerosionsmessprogramm Sachsen-Auswertung der Beregnungsversuche 29-49 vom 02.-12.05.1994; LfUG: Freiberg, Germany, 1994.

55. LfUG. Bodenerosionsmessprogramm Sachsen-Auswertung der Beregnungsversuche 50-76 vom 26.09.-12.10.1994; LfUG: Freiberg, Germany, 1995.

56. LfUG. Bodenerosionsmessprogramm Sachsen-Auswertung der Beregnungsversuche 77-94 vom 09.05.-19.5.1995; LfUG: Freiberg, Germany, 1995.

57. LfUG. Bodenerosionsmessprogramm Sachsen-Auswertung der Beregnungsversuche 95-116 vom 03.10.-13.10.1996; LfUG: Freiberg, Germany, 1996. 
58. Schmidt, J. A mathematical model to simulate rainfall erosion. In Erosion, Transport and Deposition Processes-Theories and Models; Catena Supplement; Bork, H.-R., de Ploey, J., Schick, A.P., Eds.; Catena Verlag: Cremlingen-Destedt, Germany, 1991; Volume 19, pp. 101-109.

59. Schmidt, J. Modeling long term soil loss and landform change. In Overland Flow-Hydraulics and Erosion Mechanics; Parson, A.J., Abrahams, A.D., Eds.; UCL Press: London, UK, 1992; pp. 409-433.

60. Von Werner, M. GIS-orientierte Methoden der Digitalen Reliefanalyse zur Modellierung von Bodenerosion in Kleinen Einzugsgebieten. Ph.D. Thesis, Freie Universität Berlin, Berlin, Germany, 1995.

61. Green, W.H.; Ampt, G.A. Studies on soil physics. J. Agric. Sci. 1911, 4, 1-24. [CrossRef]

62. Von Werner, M. Abschätzung Des Oberflächenabflusses Und Der Wasserinfiltration Auflandwirtschaftlich Genutzten Flächen Mit Hilfe Des Modells EROSION 3D; Endbericht; GeoGnostic: Berlin, Germany, 2004.

63. Kunth, F.; Kaiser, A.; Vláčilová, M.; Schindewolf, M.; Schmidt, J. Extensive Rill Erosion and Gullying on Abandoned Pit Mining Sites in Lusatia, Germany; EGU General Assembly: Vienna, Austria, 2015.

64. Michael, A.; Schmidt, J.; Schmidt, W. Band II: Parameterkatalog Sachsen Anwendung. In EROSION 2D/3D-Ein Computermodell zur Simulation der Bodenerosion durch Wasser; Sächsische Landesanstalt für Landwirtschaft, Sächsisches Landesamt für Landwirtschaft, Umwelt und Geologie: Dresden, Freiberg, Germany, 1996; p. 121.

65. Seibert, S.; Auerswald, K.; Fiener, P.; Disse, M.; Martin, W.; Haider, J.; Michael, A.; Gerlinger, K. Surface runoff from arable land-A homogenized data base of 726 rainfall simulation experiments. Hydrol. Earth Syst. Sci. 2011. [CrossRef]

66. LfL. Erarbeitung der Digitalen Datengrundlage für die Anwendung von EROSION-3D auf Mesoskaliger Maßstabsebene mit Durchführung einer Erosionssimulation für das zu Bearbeitende Gebiet, Endbericht des FuE-Vorhabens der LfL; GeoGnostics: Leipzig/Berlin, Germany, 2005; pp. 1-88.

67. Schindewolf, M.; Schmidt, J.; von Werner, M. Modeling soil erosion and resulting sediment transport into surface water courses on regional scale. ZfG Suppl. Issues 2013, 57, 157-175. [CrossRef]

68. DTM2 2016: Staatsbetrieb Geobasisinformation und Vermessung Sachsen. Kachelnummer 4445636 und 4445638. State 2005. Available online: http://www.landesvermessung.sachsen.de/inhalt/produkte/dhm/dgm/ dgm.html (accessed on 21 November 2018).

69. DTM10: Staatsbetrieb Geobasisinformation und Vermessung Sachsen. Kachelnummer 3905634, 3925634, 3905632 und 3925632. State 2013. Available online: http://www.landesvermessung.sachsen.de/inhalt/ produkte/dhm/dgm/dgm.html (accessed on 23 July 2019).

70. InVeKoS Online GIS v6.1. 2018: Sächsisches Staatsministerium für Umwelt und Landwirtschaft. Available online: https://www.smul.sachsen.de/gis-online/Default.aspx (accessed on 21 July 2018).

71. WMS Digitale Orthophotos (RGB) 2015: Staatsbetrieb Geobasisinformation und Vermessung Sachsen. Available online: https://geodienste.sachsen.de/wms_geosn_dop-rgb/guest? (accessed on 21 July 2018).

72. ArcGIS 2015. Esri ArcGIS 10.4.1 for Desktop, Version 10.4.1.5686. Available online: https://www.esri.de/ support-de/produkte/startset-arcgis-104 (accessed on 21 November 2018).

73. Arévalo, S.A. Simulation of a Local Flood Event in a Settling Area with EROSION 3D. Diploma Thesis, TU Bergakademie Freiberg, Freiberg, Germany, 2009.

74. Zemke, J. Runoff and Soil Erosion Assessment on Forest Roads Using a Small Scale Rainfall Simulator. Hydrology 2016, 3, 25. [CrossRef]

75. Müller, J.; Müller, G. Berechnung der Verdunstung landwirtschaftlicher Produktionsgebiete, 1. Mitteilung. Z. Meteorol. 1988, 38, 332-336.

76. Müller, J.; Müller, G. Berechnung der Verdunstung landwirtschaftlicher Produktionsgebiete, 2. Mitteilung. Z. Meteorol. 1988, 38, 361-365.

77. Müller, J.; Müller, G. Berechnung der Verdunstung landwirtschaftlicher Produktionsgebiete, 3. Mitteilung. Z. Meteorol. 1989, 39, 142-149.

78. Wendling, U.; Schellin, H.-G. Neue Ergebnisse zur Berechnung der potentiellen Evapotranspiration. Z. Meteorol. 1986, 36, 214-217.

79. Turc, L. Évaluation des besoins en eau d'irrigation, évapotranspiration potentielle, formule simplifiée et mise à jour. Ann. Agron. 1961, 12, 13-49.

80. Müller, J.; Böttcher, F.; Schmidt, M. Bestimmung bodenabhängiger Klimafeuchtezahlen für verschiedene Standorte in den mittleren und nordöstlichen Regionen Deutschlands. Hercynia, N. F. 2008, 41, 189-200. 
81. Land Viewer 2018: EOS Data Analytics, Inc. Available online: https://eos.com/landviewer (accessed on 21 July 2018).

82. Agisoft 2016. Agisoft PhotoScan Professiona; Version 1.2.5 Build 2735 (64 bit); Agisoft LLC: St. Petersburg, Russia, 2016; Available online: http://www.agisoft.com/ (accessed on 21 November 2018).

83. Peters, T. Ableitung einer Beziehung zwischen der Radarreflektivität, der Niederschlagsrate und weiteren aus Radardaten abgeleiteten Parametern unter Verwendung von Methoden der multivariaten Statistik. Ph.D. Thesis, Universität Fridericiana zu Karlsruhe (TH), Karlsruhe, Germany, 2008.

84. Einfalt, T.; Frerk, I. The challenge to estimate extreme precipitation for locations without rain gauges. In Proceedings of the ERAD 2012-The seventh European Conference on Radar in Meteorology and Hydrology, Toulouse, France, 25-29 June 2012.

85. DWD RADOLAN/RADVOR-OP (Sachstand und Ausblick). Available online: https://www.dwd.de/DE/ leistungen/radolan/radarniederschlagsprodukte/vortrag_2010_pdf (accessed on 15 December 2017).

86. Hänsel, P.; (Technical University Bergakademie Freiberg, Freiberg, Saxony, Germany). Personal photography. 2016.

87. Hebenstreit, F.; (DB Netz AG, Dresden, Saxony, Germany). Personal Communication, 2018.

88. DWD Änderung des Inputs beim RY-Radarprodukt und zwei neue Summenprodukte. RADOLAN-Info Nr. 45. Available online: https://www.dwd.de/DE/leistungen/radolan/radolan_info/radolan_info_nr_45.pdf? blob=publicationFile\&v=3 (accessed on 21 July 2019).

89. DWD Inbetriebnahme des Ausfallsicherungsradars Borkum und Abschaltung des Radars Emden sowie Änderung des Inputs beim RO- und RZ-Radarprodukt. RADOLAN-Info Nr. 46. Available online: https://www.dwd.de/DE/leistungen/radolan/radolan_info/radolan_info_nr_46.pdf?_blob= publicationFile\&v=2 (accessed on 21 July 2019).

90. DWD Start der Bereitstellung der Testproduktion POLARA_*. RADVOR-Info Nr. 19. Available online: https://www.dwd.de/DE/leistungen/radvor/radvor_info/radvor_op_info_nr_19.pdf? blob=publicationFile\&v=2 (accessed on 21 July 2019).

(C) 2019 by the authors. Licensee MDPI, Basel, Switzerland. This article is an open access article distributed under the terms and conditions of the Creative Commons Attribution (CC BY) license (http://creativecommons.org/licenses/by/4.0/). 